\section{Ankara Üniversitesi Eğitim Bilimleri \\ Fakültesi Özel Eğitim Dergisi}

2021, 22(4), 895-919
ARAŞTIRMA

Gönderim Tarihi: 04.05.20

Kabul Tarihi: 23.02.21

Erken Görünüm: 11.03.21

\title{
Zihin Yetersizliği Olan Öğrencilerin Devam Ettiği Destek Eğitim Odası Hizmetine Yönelik Bir Durum Çalışması*
}

\author{
Didem Güven 1
}

$\ddot{O} \mathbf{z}$

Giriş: Kaynaştırma uygulamaları kapsamındaki destek eğitim odası (DEO) hizmeti, mevzuatta yer almasına karşın son dönemlerde ülkemizde fiili olarak sunulmaya başlamış ve bu hizmetin nasıl sunulacağı tartışılır hale gelmiştir.

Yöntem: Bu nedenle bu çalışma DEO’nun temel boyutları olan yönetim, rehberlik ve uygulama boyutlarının nasıl işlediğini bütün olarak görmek, betimlemek ve sonucunda çözüm önerileri sunmak amaciyla nitel araştırma yöntemlerinden iç içe geçmiş tek durum çalışması olarak gerçekleştirilmiştir. Bu doğrultuda belirtilen her bir boyutun sorumluları olan 10 okul yöneticisi, 10 rehber ve 10 DEO öğretmeniyle yarı-yapılandırılmış görüşmeler gerçekleştirilmiştir. Katılımcıların okullarında DEO’nun fiziksel ortamına ilişkin geliştirilen kontrol listeleri kullanılmıştır. Ayrıca araştırmacı, DEO'nun işleyişini betimlemek için bir okulun iki ayrı DEO'sunda saha notları tutmuş; süreç boyunca araştırmacı günlüğüne görüşlerini yansıtmıştır.

Bulgular: Yapılan analiz sonucunda fiziksel ortama, paydaşların görüşlerine ve DEO'nun işleyişine ilişkin üç tema ortaya çıkmıştır. Araştırma sonucunda, DEO'ların fiziksel ortamının yetersiz olduğu, rehber öğretmen ve yöneticilerin DEO sürecinin lideri olduğu, DEO’da sadece öğretim hizmeti sağlandığı, danışmanlık hizmetinin sunulmadığı görülmüştür; katılımcıların DEO bilgilerinin yetersiz olduğu anlaşılmıştır.

Tartışma: Araştırma sonucunda DEO hizmeti süreçlerin sağlıklı işlemediği, katılımcıların DEO bilgilerinin yeterli olmadığı ortaya çıkmıştır. DEO'da öğretmenlerin sadece öğretim yaptıkları, DEO konusunda lider kişilerin okullardaki rehber öğretmenlerle okul yöneticileri olduğu anlaşılmıştır. Belirtilen bu olumsuz durumların üstesinden gelmek için DEO'lara özel eğitim öğretmeni ataması önerilmiştir.

Anahtar sözcükler: Kaynaştırma uygulamaları, destek eğitim odası, zihin yetersizliği, okul yöneticileri, rehber öğretmenler, destek eğitim odası öğretmeni.

Atıf için: Güven, D. (2021). Zihin yetersizliği olan öğrencilerin devam ettiği destek eğitim odası hizmetine yönelik bir durum çalışması. Ankara Üniversitesi Ĕ̆itim Bilimleri Fakültesi Özel Eğitim Dergisi, 22(4), 895-919. https://doi.org/10.21565/ozelegitimdergisi.731858

\footnotetext{
*Bu çalışma doktora tezinden üretilen bir çalışma olup 29. Ulusal Özel Eğitim Kongresinde sözlü bildiri olarak sunulmuştur. ${ }^{1}$ Sorumlu Yazar: Dr. Öğr. Üyesi, İstanbul Sabahattin Zaim Üniversitesi, E-posta: didem.guven@izu.edu.tr, http://orcid.org/0000-0002-5388-6963
} 


\section{Giriş}

Kaynaştırma uygulamaları (KU) kapsamındaki destek özel eğitim hizmetleri oldukça geniş bir çerçeveye sahip olup kendi içinde farklı şekillerde sunulmaktadır. Bunlar; sınıf içi yardım, özel eğitim danışmanlığı ve kaynak oda hizmetidir (Batu, 2000). Kaynak oda, ülkemizde yakın dönemde uygulamalarda yerini almış ve Millî Eğitim Bakanlığı (MEB) mevzuatında "Destek Eğitim Odası (DEO) Hizmeti” olarak tanımlanmıştır (Özel Eğitim Hizmetleri Yönetmeliği [ÖEHY], 2018). Bu kapsamlı hizmet modelinde, ayrı bir eğitim ortamında, özel eğitim öğretmeni tarafından sunulan eğitimle genel ve özel eğitim arasında öğretimsel boşluklar doldurulmaktadır (Robbins, 2014). Böylelikle DEO, özel gereksinimli öğrencinin (ÖGÖ) gereksinimine göre matematik, okumayazma gibi akademik alanlarla, günlük yaşam ve sosyal becerileri, davranış problemleri gibi belirlenmiş bir veya birden çok alana göre bireyselleştirilmiş müdahalelerde bulunulan belirtilen alanlarda iyileştirme yapılan yer olarak açıklanmaktadır (Robbins, 2014; Watson, 2018). Alanyazında yapılan bu açıklamalar, DEO'nun bileşenlerini belirleyerek her bir bileşenin araştırılmasına, ayrıntılı olarak açıklanmasına katkıda bulunmuştur. Alanyazındaki birçok kaynak okul yöneticisi (OY), rehber öğretmen (RÖ) ve DEO öğretmeni gibi kritik konumdaki paydaşlar ve fiziksel ortam, DEO'nun bileşenleri olarak belirtilerek açıklanmıştır (Cohen, 1982; Jamaica Ministry of National Education [JMNE], 2006; MEB, 2016).

DEO, ilk kez Özel Eğitim Hizmetleri Yönetmeliğinde (ÖEHY, 2000) tanımlansa da 2015’te yayınlanan genelge sonrasında okullarda fiili olarak yerini almıştır. Dolayısıyla bu yeni hizmetin kritik boyutlarını anlamak, çözüm üretmek, DEO hizmetinde oluşacak karmaşanın önüne geçerek bu hizmete yönelik geliştirilecek eğitim politikalarına bir yol haritası çizmek adına, bu çalışma önem arz etmektedir. Bu noktada alanyazında yapılan çalışmalara değinmek gerekir. Baumgartner (1979), DEO'da küçük grupta öğretilen çıkarma becerisinin genel eğitim sınıfında genellenmesini araştırmış; küçük grup öğretiminin etkili olduğunu belirlemiştir. Saxon (2007), DEO'da hizmet alan zihin yetersizliği (ZY) olan öğrencilerin genel eğitim sınıfına uyum sürecini etnografik durum çalışmasıyla araştırmış, okulun şartlarının ve kapasitesinin uygun olduğu sürece, ÖGÖ’nün yetersizliğine bakılmaksızın istenilirse genel eğitim sınıflarına uyum sağlamasının zor olmayacağı sonucuna varmıştır. PoonMcBrayer (2016), DEO öğretmenlerinin KU ve DEO'ya ilişkin anketlerle görüşlerini almış ve DEO öğretmenlerinin sınırlı DEO bilgisi ve çok fazla iş yükünün olduğu sonucuna ulaşmıştır. Sabbah \& Shanaah (2019), DEO’ya ilişkin OY, RÖ ve DEO öğretmeninin görüşlerini yarı-yapılandırılmış görüşmelerle belirlemişler ve katılımcıların \%78'i DEO’dan memnuniyet bildirmişlerdir.

Türkiye'deyse günümüze doğru geldikçe DEO’ya ilişkin farklı tanı gruplarıyla yapılan araştırmalarda artış görülmüştür. Sayan (2019), okul öncesi dönemde DEO’dan faydalanan ÖGÖ’lerdeki gelişmeyi öntest-sontest yöntemiyle değerlendirerek ÖGÖ’lerde öz bakım, psikomotor, bilişsel, sosyal ve duygusal, dil gelişiminde önemli ilerlemeler olduğunu saptamıștır. Aslan (2019), geliștirdiği anketle öğretmenlerin DEO konusunda görüşlerini almıştır. Araştırma sonucunda DEO'da BEP uygulamalarında sorunlar olsa da DEO konusunda öğretmenlerin iş birliği yaptıkları ortaya çıkmıştır. Talas ve diğerleri (2016), öğretmenlerle yaptıkları karma çalışmalarında, DEO'nun fiziksel ortamındaki yetersizliğe dikkat çekerek, DEO öğretmenlerinin yaşadıkları bilgi eksikliğini bildirmişlerdir. Pesen'nin (2019) karma çalışmasının sonucu da DEO'da geleneksel yöntemlerle öğretimin sürdüğü, fiziksel koşullardaki yetersizliği ortaya konulmuştur.

Farklı araştırmacılar, DEO paydaşlarından DEO öğretmenleri, aileler, OY ve ÖGÖ’lerle yarıyapılandırılmış görüşmeler gerçekleştirmişlerdir. Bu çalışmaların bulgularında genel olarak DEO öğretmenlerinin bilgisizliği, fiziksel ortam yetersizlikleri, geleneksel yöntemlerle öğretim yapılması, aile iş birliğinin zayıflığı bildirilirken olumlu olarak ÖGÖ’lerde ilerlemeler bildirilmiştir. Bu araştırmalarda DEO'larda iş birliğinin ve destek hizmet saatlerinin artırılması gerektiği de öneri olarak sunulmuştur (Aydın, 2015; Çağlar, 2016; Dalga, 2019; Filig, 2019; Kaplan, 2019; Semiz, 2018; Yazıcığlu, 2020). Bu sonuçlar yapılan durum çalışmalarında da tespit edilmiştir (Kotil, 2019; Tamas, 2020; Yazçayır, 2020). Ancak bu araştırmalardan hiçbiri nörogelişimsel bozukluk çatısında olan ZY, dikkat eksikliği ve hiperaktivite bozukluğu, yaygın gelişimsel bozukluk gibi tanılarla gerçekleştirilmemiştir. Bu nedenle bu çalışmayla nörogelişimsel bozukluğu olan bireylere DEO'da sunulan hizmetin nasıl olduğu anlaşılmaya çalışılarak alandaki bu boşluğun doldurulması hedeflenmiştir.

Türkiye'de alanyazına DEO konusunda öncü bir çalışma olması ve DEO hizmetinin teorik temellerinin bu çalışmayla atılması hedeflenmiştir. Dolayısıyla araştırmanın amacı, DEO hizmeti ve bu hizmetin genel eğitim okullarındaki işleyişine ilişkin temel paydaşlar olarak DEO öğretmeni, OY ve RÖ’lerin görüşlerini alıp DEO'nun fiziksel koşullarının ve işleyişinin nasıl olduğunu belirlemektir. Bu amaç doğrultusunda aşağıdaki sorulara yanıt aranmıştır: 
1. OY'lerinin DEO hizmeti, rol ve sorumluluklarına ilişkin görüşleri nelerdir?

2. RÖ'nün DEO hizmeti, rol ve sorumluluklarına ilişkin görüşleri nelerdir?

3. DEO öğretmeninin DEO hizmeti, rol ve sorumluluklarına ilişkin görüşleri nelerdir?

4. DEO'nun fiziksel koşulları nasıldır?

5. DEO'nun işleyişi nasıldır?

6. DEO'nun ÖGÖ’ye sağladığ katkılar nelerdir?

\section{Yöntem}

\section{Araştırma Modeli}

Araştırmada, yeni bir hizmet olan DEO'nun yönetim, rehberlik ve uygulama boyutlarının bütün olarak nasıl işlediğini betimlemek amaçlandığından "betimleme amaçlı durum çalışması" olarak desenlenmiştir. Ayrıca durum çalışmasının türüne bağlı olaraksa iç içe geçmiş durum çalışması olarak gerçekleştirilmiştir. İç içe geçmiş durum deseninde tek bir bağlamda iki ayrı durumun araştırılması söz konusu olmaktadır. Bu çalışmada tek bir okulun iki farklı DEO bağlamında veriler toplanmıştır. Bu bağlamlarda öğretmenler ve öğrencilerin DEO hizmeti süreci gözlenmiştir. Bu araştırmanın durumları Şekil 1'de Yin'den (2003) uyarlanarak görselleştirmiştir.

\section{Şekil 1}

Araştırmanın İ̧̧ İ̧e Geçmiş Tek Durum Deseni Modeli

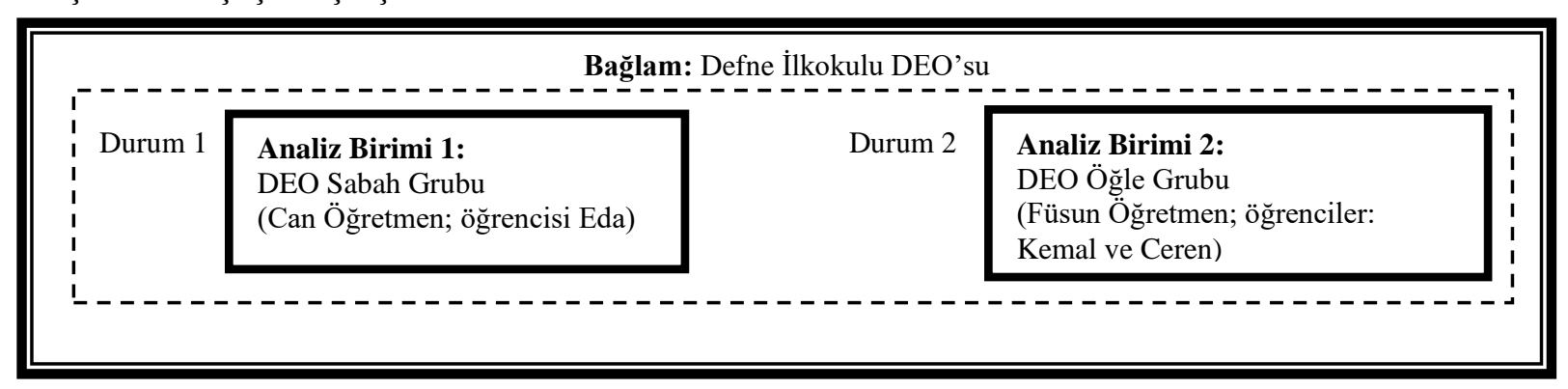

\section{Çalışma Grubu}

Araştırmanın çalışma grubunu oluşturan katılımcılar, iki grup olarak ele alınmıştır. Araştırmanın ilk grubunu $10 \mathrm{OY}, 10 \mathrm{RÖ}$ ve $10 \mathrm{DEO}$ öğretmeni oluşturmaktadır. Bu kişilerle yarı-yapılandırılmış görüşmeler gerçekleştirildiği için ilk grup katılımcı olarak adlandırılmıştır. Görüşmeye katılan OY’nin tamamı erkektir. Sekizi lisans, diğerleri yüksek lisans ve doktora mezunudur, en az 11 yıldır öğretmenlik mesleğini sürdürmektedirler. Tamamının KU ve DEO deneyimleri mevcuttur; çoğu 16 yılı aşkın süredir yöneticilik yapmaktadır. RÖ’lerin, altısı kadın, dördü erkektir. Çoğunun üç yıldan fazla KU deneyimleri vardır, iki yılı aşkın süredir DEO hizmeti sunana bir okulda görev yapmaktadır. Tamamına yakını ikinci bir RÖ ile çalıșmaktadır. DEO öğretmenlerin, dokuzu erkek, biri kadındır. En az 11 yıllık öğretmenlerdir. Bir öğretmen işaretlediği formda gönüllü olarak görev yapmadığını bildirmiştir. Dört öğretmen norm fazlasıdır. Sadece iki öğretmen DEO’ya ilişsin hizmet içi eğitim almıştır.

İkinci gruptaki katılımcılarsa odak okul olan Defne İlkokulu öğretmenleriyle ÖGÖ’lerden oluşturmaktadır. Bu gruptaki öğretmenler, ilk grupta görüşme yapılan kişiler arasında olup saha notlarının (SN) tutulduğu odak okulda, merkezi bir konuma sahip oldukları için detaylı bir şekilde Tablo 1'de betimlenmişlerdir. 


\section{Tablo 1}

Defne İlkokulunda Görev Yapan Öğretmenlere İlişkin Demografik Bilgiler

\begin{tabular}{cclccc}
\hline $\begin{array}{c}\text { Öğretmenin } \\
\text { kod adı }\end{array}$ & $\begin{array}{c}\text { Öğretmenin } \\
\text { mevzuattaki rolü }\end{array}$ & Mezun olduğu bölüm & $\begin{array}{c}\text { Öğretmenin } \\
\text { cinsiyeti }\end{array}$ & $\begin{array}{c}\text { Meslekteki görev } \\
\text { süresi (Yıl) }\end{array}$ & $\begin{array}{c}\text { DEO rol ve } \\
\text { sorumluluğu }\end{array}$ \\
\hline $\begin{array}{c}\text { Ahmet } \\
\text { Kemal }\end{array}$ & $\begin{array}{c}\text { Okul müdürü } \\
\text { Müdür yardımcısı }\end{array}$ & $\begin{array}{l}\text { Sinıf öğretmenliği } \\
\text { Sinıf öğretmenliği }\end{array}$ & $\begin{array}{c}\text { Erkek } \\
\text { Kadın }\end{array}$ & 20 & $\begin{array}{c}\text { Yönetici } \\
\text { Yönetici }\end{array}$ \\
Deniz & Rehber öğretmen & $\begin{array}{c}\text { Psikolojik danışma ve } \\
\text { rehberlik }\end{array}$ & Kadın & 9 & $\begin{array}{c}\text { Psikolojik danışma ve } \\
\text { rehberlik } \\
\text { Psikolojik danışma ve } \\
\text { rehberlik }\end{array}$ \\
Fur & Rehber öğretmen & Felsefe öğretmenliği & Kadın & 9 & $\begin{array}{c}\text { DEO’da } \\
\text { görevlendirilme } \\
\text { DEO'da } \\
\text { görevlendirilme }\end{array}$ \\
\hline
\end{tabular}

Not: DEO = destek eğitim odası.

Öğretmenler, ölçüt örneklem yöntemiyle seçilmiştir. Bu ölçütler, gönüllü olarak araştırmaya katılma, ÖGÖ’lerle çalışmış/çalışıyor olma, MEB'e bağlı DEO'su olan resmi bir ilkokulda çalışma, öğretmenlik mesleğinde en az beş yıl deneyimli olmadır. İkinci katılımcı grubunda olan ÖGÖ’lere ait bilgiler Tablo 2'de sunulmuştur.

Tablo 2

Defne İlkokulu DEO'suna Devam Eden Öğrencilere Ait Bilgiler

\begin{tabular}{|c|c|c|c|c|c|c|c|c|c|}
\hline $\begin{array}{c}\text { DEO } \\
\text { bağlamları }\end{array}$ & $\begin{array}{c}\text { DEO } \\
\text { öğretmen } \\
\text { adı ve yaşı }\end{array}$ & $\begin{array}{l}\text { Dersten } \\
\text { alınması } \\
\text { (Pull-out) }\end{array}$ & $\begin{array}{l}\text { Devre } \\
\text { ve } \\
\text { sinif }\end{array}$ & Öğrenci & $\begin{array}{l}\text { Cinsiyet } \\
\text { ve yaş }\end{array}$ & Tanı & $\begin{array}{l}\text { DEO } \\
\text { ders } \\
\text { saati }\end{array}$ & $\begin{array}{c}\text { Farklı } \\
\text { destek alma } \\
\text { durumu }\end{array}$ & $\begin{array}{c}\text { İyileştirilmesi } \\
\text { hedeflenen } \\
\text { dersler }\end{array}$ \\
\hline Durum 1 & $\begin{array}{c}\text { Can } \\
57\end{array}$ & $\checkmark$ & Sabah & Eda & $\begin{array}{l}\text { Kadın } \\
\quad 9\end{array}$ & $\begin{array}{c}\text { HDZY } \\
+ \\
\text { DEHB }\end{array}$ & 8 & Yok & $\begin{array}{c}\text { Türkçe } \\
\text { Matematik }\end{array}$ \\
\hline Durum 2 & $\begin{array}{c}\text { Füsun } \\
44\end{array}$ & $\checkmark$ & Öğlen & Kemal & $\begin{array}{c}\text { Erkek } \\
10\end{array}$ & YGB & 10 & $\begin{array}{c}\text { İlaç ve } \\
\text { psikolojik } \\
\text { destek }\end{array}$ & $\begin{array}{c}\text { Fen bilimleri } \\
\text { Sosyal bilgiler } \\
\text { Türkçe } \\
\text { Matematik }\end{array}$ \\
\hline Durum 2 & $\begin{array}{c}\text { Füsun } \\
44\end{array}$ & $\checkmark$ & Öğlen & Ceren & $\begin{array}{c}\text { Erkek } \\
10\end{array}$ & $\begin{array}{c}\text { HDZY } \\
+ \\
\text { DEHB }\end{array}$ & 10 & İlaç & $\begin{array}{c}\text { Fen bilimleri } \\
\text { Sosyal bilgiler } \\
\text { Türkçe } \\
\text { Matematik }\end{array}$ \\
\hline
\end{tabular}

Not: HDZY = hafif düzeyde zihinsel yetersizlik; DEHB = dikkat eksikliği ve hiperaktivite bozukluğu; YGB = yaygın gelişimsel bozukluk.

ÖGÖ’lerin özellikleri, araştırmacının uzmanlık alanına göre belirlenmiştir. Araştırmacının çalışma alanı ZY olan öğrenciler olması nedeniyle ZY ve YGB tanılı öğrenciler çalışmaya dâhil edilmiştir.

\section{Ortam}

Araştırmada iki farklı ortam bulunmaktadır. Bu ortamlar, ölçüt örnekleme yöntemiyle belirlemiştir. Bu ölçütler; okulların il merkezindeki ilçelerinde bulunması, alt-orta-üst gelir düzeyindeki çocukların bir arada bulunması, görüşmelere katılan öğretmenlerin görev yaptığı okullardan oluşmasıdır. İlk ortamı Defne İlkokulu DEO'sudur. Bu DEO, SN'nin tutulan odak ortamdır ve diğer 11 DEO'dan ayrı tutulmuştur. İkinci gruptaki ortamsa DEO'larda kontrol listelerinin kullanıldığı 12 ilkokulun DEO'sudur. Bu 12 okulun içinde Defne İlkokulu'nun DEO'su da bulunmaktadır. Bu ortamlarda, “DEO’nun fiziksel ortamını nasıldır?” sorusunun yanıtı aranmıştır.

\section{Veri Toplama Araçları}

Araştırmada farklı veri toplama araçları kullanılmıştır. Tüm veri toplama araçları alanyazına (Cohen, 1982; Desphande, 2013; JMNE, 2006; MEB, 2016; ÖEHY, 2012; Poon-McBrayer, 2016) bağlı olarak geliştirilmiş, özel eğitim alan uzmanlarına gönderilerek 12 uzmanın görüşüne göre şekillendirilmiştir. Son hali verilen veri toplama araçları için pilot çalışmalar gerçekleştirilerek pilot çalışmaya dâhil olan okullar ve katılımcılar araştırmaya dâhil edilmemiştir. 


\section{Saha Notlart}

Katılımcı gözlemci olarak araştırmacının, araştırma sorusuna bağlı DEO ortamında gördüğü, duyduğu her şeyi davranışsal olarak yazılı not etmesidir. Temel veri toplama aracı olarak DEO'daki eğitim öğretim sürecini kaydetmek için “DEO Gözlem Formu” geliştirilmiştir. Bu form üç sayfadan oluşmaktadır. İlk sayfada DEO’ya ilişkin genel bilgiler; ikinci sayfada eğitim ortamıyla sürecine ilişkin detaylı bilgiler; son sayfadaysa notlar başlığ bulunmaktadır. SN, video görüntüleriyle desteklenmiştir. Bu formu kullanmadaki amaç, DEO’da öğretim sürecinde neler olduğunu detaylı şekilde anlayarak akabinde yorumlamaktır.

\section{Yarı Yapılandırılmış Görüşme Formları}

DEO öğretmeni, RÖ, OY’lerine yönelik DEO hakkında soruların olduğu formlardır. Bu formlarda DEO'nun işleyişi sürecinde kişilerin rol ve sorumluluklarını ifade etmelerine olanak veren ve DEO bilgisini anlamaya yönelik sorulardan oluşmaktadır. RÖ ve OY'ye 11, DEO öğretmenine 10 açık uçlu soru hazırlanmıştır.

\section{Kontrol Listeleri}

DEO’nun fiziksel koşulları, materyalleri ve donanımına ilişskin geliştirilen üç farklı kontrol listesi (KL)'dir. Fiziksel koşullara ilişkin 18; donanıma ilişkin 39; materyale ilişkin 47 sorudan oluşmaktadır. KL'lerinin ilk sayfasında okullara ilişkin bilgiler olup araştırmacının işaretlenmesi gerektirmektedir. İkinci sayfasındaysa KL'nin ilgili soruları sıralanmıştır.

\section{Kişisel Bilgi Formları}

Görüşme öncesinde katılımcılardan doldurulması istenen formlardır. $\mathrm{Bu}$ formlar branşlara göre oluşturulmuştur. Formlarda katılımcılar, kişisel ve mesleki bilgileri, DEO rol ve sorumluluklarına ilişkin özellikleri, özel eğitim ve KU bilgilerini işaretlemektedirler. Formlarda OY'e 18, RÖ’lere 16 ve DEO öğretmenine 23 soru sorulmuştur.

\section{Araştırmacı Günlü̆̆̈̈ (AG)}

Araştırmacının araştırma boyunca her türlü görüşleriyle önerilerini öznel şekilde süreci detaylı olarak not aldığı defterdir. AG, ikincil veri toplama kaynağıdır. Bulgular, AG’den elde edilen verilerle desteklenmiştir.

\section{Resmi Dokümanlar}

DEO’ya ilişkin BEP'ler, resmi yazılar ve BEP birimi toplantı tutanaklarından oluşmaktadır, ikincil veya dolaylı veri olarak bulgulara yansıtılmıştır. Resmi dokümanlar, iki gruba ayrılmaktadır. Birinci grupta tüm ülkeyi kapsayan resmi yazılar bulunmaktadır. İkinci gruptaysa şehri, okulu ve öğrenciyi ilgilendiren evraklarla gözlenen ÖGÖ'lere ait üç BEP'ten oluşmaktadır.

\section{Öğrenci Ürün Dosyalart}

DEO gözlenen ÖGÖ’lerin öğretim sürecini destekleyen ikincil kaynaklardır. Sadece Durum 2'de Kemal ve Ceren'e ait ürün dosyalarına ulaşılmıştır. Dosyalarda, DEO'da gerçekleştirilen Türkçe, Matematik, Fen Bilgisi, okuma-yazma gibi derslere ilişkin ayrıntılı bilgiler vermektedir.

\section{Verilerin Toplama ve Analizi}

Araştırmanın verileri 2016-2017 eğitim öğretim yılında toplanmıştır. Temel veri toplama aracı, SN'lerini desteklemek amacıyla diğer veri toplama araçları kullanılmıştır. Defne İlkokulunda Durum 1'de 28; Durum 2'deyse $24 \mathrm{SN}$; her iki durumun sırasıyla 27 ve 23 görüntü kaydedilmiştir. SN'lerin görüntülerden fazla olma nedeni DEO'da ders akışını bozmadan katılımcıların öncelikle araştırmacıya alışmasını sağlamaktır. Görüşmelerse üç branştan 30 paydaşla gerçekleştirilmiştir. Görüşmeler, belirlenen görüşme ilkelerine bağlı olarak birebir olacak şekilde, görüşme öncesinde karşılıklı katılımeı formları imzalanarak, kişisel bilgi formları doldurulduktan sonra gerçekleştirilmiştir. Ayrıca ölçütleri sağlayan 12 okulun DEO’sunda KL’leri işaretlenmiştir. Resmi dokümanlarla Durum 2’ye ait öğrenci ürün dosyalarıysa süreç boyunca toplanmıştır.

Video görüntüleri, ABC kaydı şeklinde ayrıntılı videoteyp gözlem formuna; SN arşivlenerek veri analizini kolaylaştırmak amacıyla dijital ortamda kaydedilmiştir. Görüşmelerin dökümünden sonra yarıyapılandırılmış görüşme formuna aktarılmıştır. Görüşmelerle SN verilerinin analizinde tümevarım yöntemi kullanılmıştır. Kişisel bilgi formlarından edinilen demografik veriler, branşlara göre bir araya getirilerek üç ayrı tablo halinde sunulmuştur. KL'lerse DEO’nun fiziksel koşulları, materyalleri ve donanımı başlıkları şeklinde üç 
farklı tablo olarak betimlenmiştir. Resmi dokümanlardaki bilgiler, ÖGÖ’lere ait ürün dosyalarının bir araya getirildikten sonra üstünde işaretlemeler yapılarak, görüşmelerle SN'lerden elde edilen temaları desteklemesi için hazır hale getirilmiştir.

Araştırmada geçerlik ve güvenirlik çalışmaları gerçekleştirilmiş, sırasıyla açıklanmıştır. Araştırmada, inandirıcılık çalışması için; çoklu ve farklı ortamlardan veri toplama, uzman görüşüne başvurma, katılımcı teyidi yapılarak, veri dökümlerinin saklanması sağlanmıştır. Teyit edilebilirliğini sağlamak için tüm verilerin dökümünden sonra ilk güvenirlik, kodlama ve kod listesi oluşturma, kodlama güvenirliği, tema ve alt temalarının oluşturulmasıyla tema ve alt temaların yazımıyla düzenlenmesi çalışmaları yapılmıştır. Kodlamacılar arası güvenirlik çalışmaları da yapılarak şu basamaklar izlenmiştir: Görüntüler, SN'yle görüşmeler rastgele seçilen \%30’u üç uzmana gönderilmiștir. İlgili çalıșmanın sonunda görüntülerin güvenirlik ortalaması \%89, SN'nın güvenirlik ortalaması $\% 89$, görüşmelerin güvenirlik ortalamasıysa $\% 99$ olarak hesaplanmıştır. Belirtilen veri toplama araçlarının ortalama güvenirliğiyse $\% 92$ olarak belirlenmiştir. Aktarılabilirlik adına amaçlı örneklem yöntemi kullanılmıştır. SN'den elde edilen veriler, katılımcı görüşlerinden ve dokümanlardan yararlanılarak ayrıntılı betimlemelerle sunulmuștur. Tutarlılık için süreç boyunca çoklu veri toplanmıștır. Böylece verilerin birbirini desteklemesi sağlanmıştır. Araştırmanın etik boyutundaysa sırasıyla araştırmanın gerçekleştiği Anadolu Üniversitesi etik kurulundan E.138135 protokol numarasıyla, araştırmanın gerçekleştiği İl Milli Eğitim Müdürlüğü'nden (MEM), katılımcılardan, ÖGÖ’lerin velilerinden gerekli izinler yazılı olarak alınmıştır. Katılımcılara kod adı verilmiştir.

\section{Bulgular}

$\mathrm{Bu}$ bölümde veri toplama araçlarından edinilen verilerin analizi sonucunda ortaya çıkan bulgulara yer verilmiştir. Araştırma bulguları üç ana tema şeklinde ortaya çıkmıştır. Bu ana temalar ve ana temalara bağlı oluşturulan alt temalar aşağıda Şekil 2'de detaylı olarak gösterilmiştir.

\section{Şekil 2}

DEO'nun Yönetim, Rehberlik ve Uygulama Boyutuna İlişkin Bulguları

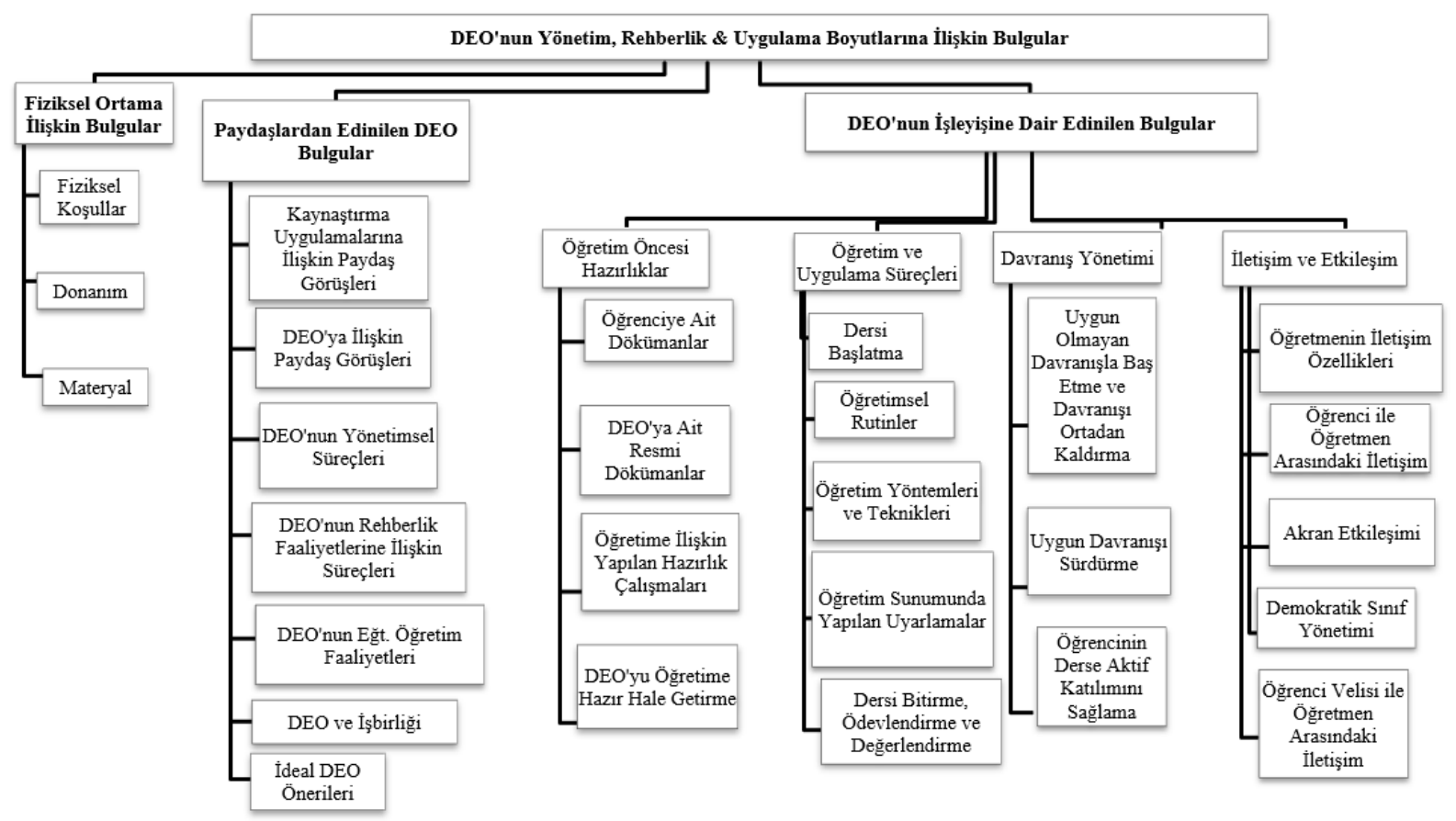

\section{DEO'nun Fiziksel Ortamına İlişskin Bulgular}

Şekil 2'de görüldüğü üzere KL'lerden fiziksel ortam verileri, donanım, materyal ve fiziksel koşullar olarak üç alt tema olarak ortaya çıkmıştır. Fiziksel koşullar KL'deki yedi maddenin hiçbir DEO'da sağlanmadığı, iki maddeninse DEO'larda kısmen sağlandığ görülmüştür. Donanım KL'deki malzemelerden 15'inin hiçbir DEO'da olmadığı, geri kalan malzemelerinse farklı DEO'larda olduğu görülmüştür. Materyal KL'de 15 
materyalin hiçbir DEO'da olmadığı, diğer malzemelerinse farklı DEO'larda olduğu anlaşılmıştır. Görüşmelerde katılımcıların yarısı materyal eksikliğini, dokuzuysa dersliklerinin olmadığını bildirmiştir. DEO'lar, KL'de belirtilen koşulları tamamıyla sağlamamaktadır.

\section{Paydaşlardan Edinilen DEO Bulguları}

Katılımcılar; KU ve DEO’ya ilişkin görüşler, DEO'nun yönetimsel süreçleri, rehberlik faaliyetleri, eğitim öğretim faaliyetleri, DEO ve iş birliğiyle ideal DEO önerileri alt temalarında görüşlerini bildirmişlerdir. KU ve DEO’ya ilişkin görüşlerini olumlu görüşlerle yaşadıkları sorunlar olarak belirtmişlerdir.

DEO hakkında olumlu görüşler arasında DEO'ların açılmasından duyulan memnuniyet, ÖGÖ'ye sağlanan firsat eşitliği, öğretimsel çıktılar, mesleki deneyimlerle iş birliğine ilişkin sağladığı katkılar bulunmaktadır. ÖGÖ’ye firsat eşitliğini RÖ Nafi Bey: “...destek eğitim, çocuklara firsat eşitliği konusunda yani onlara da bu imkânın verilmesi son derece olumlu...” şeklinde anlatmıştır.

DEO'da yaşadıkları sorunları da katılımcılar belirtmişlerdir. Yaşar Bey, DEO'da gönüllü görev yapmadığını kişsisel bilgi formuna işaretlemiştir. Füsun öğretmen, kendisini DEO'ya ait hissetmediğini, “...Hala destek eğitim öğretmeni olarak görmüyorum. Sadece aldığım görevi hakklyla yerine getirmek adına yani mesela ben bunu geçici yapıyorum... ” sözleriyle açıklamıştır. OY Lütfi Bey, “...destek eğitimde zihinsel öğrencilerimize ögretmenin bilgi, beceri ve yeterlilikleri noktasında sıkıntımız var." diyerek DEO öğretmenin bilgi eksikliğine değinmiştir. RÖ’ler, DEO iş yükünden şikâyetçi olmuşlardır. RÖ Hayri Bey “... iş yükümüz şundan kaynaklanıyor, yani mevzuat anlamında sıkıntı yok da diğer öğretmenlerimizin işi bilememelerinden kaynaklı diğer ögretmenlerimizin yapabileceği bazı şeyleri rehber ögrretmenler yapinca ister istemez bir iş yükü biniyor..." ifadeleriyle gerekçesini açıklamışır. RÖ’lerden Leyla Hanım da BEP hazırlamalarını olumsuz mesleki deneyim olarak bildirmiştir.

\section{DEO'nun Yönetimsel Süreçleri}

OY bu konuda benzer açıklamalarda bulunmuşlardır. Yöneticiler, DEO öğretmeni görevlendirme sorumluluğunu temel görev olarak belirterek; yönetmeliğe bağlı ve yönetmelik dişında öğretmen görevlendirdiklerini; DEO'ya fiziksel alan ve finansal kaynak sağlama, denetleme yapma, DEO'da öğretmene eğitim sunma sorumluluklarını yerine getirdiklerini söylemişlerdir. OY Sami Bey, “...öğretmen seçimimizi yaparken öncelikle... Özel eğitim konusunda eğitim almış ve sertifika almış öğretmenlerimizi tercih etmeye çalıșlyoruz. Eğer ihtiyaçtan fazla bașvuru varsa bu sertifikasında sertifika ders saat saylsı olarak en fazla eğitimden yararlanmış olan ögretmenlerimizi seçmeye çalışlyoruz. Ĕger bunda da bir eşitlik veya işte bir şey söz konusu olursa daha çok tecrübeli ögretmenlerimizi seçmeye çallşlyoruz... " açıklamasıyla öğretmen görevlendirme sürecini aktarmıştır.

\section{DEO Rehberlik Faaliyetleri}

RÖ'ler, DEO'ya yönelik destek verme, bilgilendirme, koordinatörlük ve değerlendirme yapma, DEO Çalışma Programı Hazırlama ve takibini yapmayla DEO'dan yararlanacak öğrenciyi belirleme ve görüşme yapma çalışmalarını aktarmışlardır. RÖ Nafi Bey, “...bazen çocuklara bu konuda destek olmak yani psikolojik olarak destek olmak gerekiyor. Biz bunu da yapmaya çallşlyoruz... Ders saatlerinde o sekiz saat mesela sekiz saat alıyoruz... Çocukların o sekiz saat neden orada olduğunu oradan destek alması gerektiğini o çocuklara da anlatmaya çalş̧yoruz. O çocukların yani bu süreci hasarsı atlatmaları için elimizden geleni yapmaya çalıșlyoruz... Çocuklar iște bak bu böyle olduğu için ayrı özel eğitim alyyor bu böyle. Yani o tarz sikıntılarla siniflarda doğuyor. Onlara da bu konuda... Rehberlik yapmak gerekiyor. O sinıftaki sinıf arkadaşlarına da anlatmaya çalışlyoruz..." DEO'ya yönelik verilen destekler arasında ÖGÖ’yle sınıf arkadaşlarına destek verdiklerini bildirmiştir. RÖ’ler danışmanlık hizmetine ilişkin bilgi aktarmamışlardır.

\section{DEO'da Eğitim-Öğretim Faaliyetleri}

Öğretmenler, rol ve sorumlulukları bağlamında eğitim-öğretim faaliyetlerini açıklamışlardır. Katılımcılar öğretimi; geleneksel yöntem tekniklerle, ÖGÖ'nün ilgisine ve gereksinimine göre kullanılan yöntem tekniklerle gerçekleştirdiklerini belirtmişlerdir. Öğretmenler, öğretimlerde, "aferin" gibi sosyal pekiştireçlerle birlikte farklı etkinlik pekiştireçleri kullandıklarını belirtmişlerdir. DEO'da öğretimiyse farklı kişilerle, BEP ekibiyle görüşmeler yaparak; BEP ilerlemelerine ve öğrenci ürün dosyalarına göre değerlendirdiklerini bildirmişlerdir. Bekir Bey, “...Burada ull sinıf ögretmenleriyle de tabi irtibata geçiyoruz. Öğrencinin sinıftaki başarısında artış olup olmadığını soruyoruz..." diyerek ÖGÖ’nün başarısını değerlendirme sürecini açıklamıştır. 
Öğretimsel çıktıları kapsamında katılımcılar, ÖGÖ’lerin matematik, okuma-yazma, sosyal beceri ve özbakım alanlarında gelişmeler olduğunu belirtmişlerdir. Bekir öğretmen, öğrencisinin okuma-yazmada ilerlediğini belirtirken; Füsun Hanım, öğrencisinin okuma-yazmayı öğrendiğini söylemiştir. Nuri Öğretmen, öz bakım becerisi kapsamında öğrencisinin tuvalet becerisi, el yıkamayla fermuar kapama becerilerini öğrendiğini ve öğrencisinin tuvalet becerisini edindiğini şu şekilde aktarmıştır: “....sene başında eee af buyurun tuvalet ihtiyacını bile gideremeyecek durumdayken şu an tuvalete kendisi tek başına gidebiliyor... Hatta fermuarını kapatamayacak durumdayken şu anda kapatabiliyor...”. Öğretmenler, DEO’da danışmanlık yapma rollerine ilişkin bilgi aktarmamışlardır.

\section{DEO Hizmetinde İş Birliği ve Yapılan Çalışmalar}

Katılımcılar, DEO için okul içi ve dışı çalışmalar yaptıklarını belirtmişılerdir. Katılımcılar, okul içi; DEO çalışmalarına liderlik yapma, DEO çalışma programı hazırlama, BEP birimiyle düzenli toplantı yapma ve BEP hazırlama olarak bildirmişlerdir. RÖ Deniz Hanım, DEO çalışma programını okul idaresiyle birlikte hazırladığını şu şekilde belirtmiştir: “...Örneğin kendi sınıfında Türkçe dersi işleniyorken destek ĕ̆itimde de aynı dersi görüp ayrışmaması gerektiğini kavrayıp ders programlarını birleştirmeye çalıştık... Dediğim gibi bu konuda yöneticinin çok büyük bir desteği oldu. Biz de rehberlik servisi olarak destek sunduk. Karşılıklı bir program oluşturduk...”. Okul dışındaysa sadece yöneticiler RAM'la DEO hakkında bilgi alışverişi yaptıklarını, MEM'le DEO açma onayı hakkında koordineli çalıştıklarını aktarmışlardır.

\section{Paydaşların İdeal DEO Önerileri}

Paydaşların çoğunluğu öğretim faaliyetlerine değinmişlerdir. DEO’larda farklı etkinlik köşeleri; görsel dokunsal, dikkat geliştirici ve oyun etkinlikleriyle drama etkinlikleri olması gerektiğini belirtmişlerdir. DEO'larda küçük grup eğitiminin verilmesini; gerektiğinde tipik gelişen öğrencilerin DEO'dan faydalanması sunulan öneriler arasındadır. RÖ Deniz Hanım tanı fark etmeksizin tüm öğrencilerin DEO'dan faydalanmasını şu sözleriyle belirtmiştir: “...Hâlbuki bilmiyorum destek eğitimde neden sadece kaynaştırma öğrencileri ya da raporlu ögrencilerin olması gerekiyor. Ben ona taklliyorum evet ihtiyaçların doğrultusunda elenerek bazı maddeler eklenebilir, evet işte rapor olmadan da şu ihtiyaçları eksik olan ögrencilere bu uygulamalar devam ettirilebilir deseydi keşke. Bir rapora bağlı kalmak bence destek ĕgitimin en olumsuz özelliği. Evet, amacımız kaynaştırma ögrencilerini kaynaştırıp normal öğrencilerle beraber devam ettirmekse onların da bir eksikleri var...”.

Paydaşlar, MEB'den DEO hakkında seminer, hizmet içi eğitimle, DEO kılavuzu, denetleme ve DEO'da yardımcı personel görevlendirme talep etmişler; fiziksel ortamın düzenlenmesini, DEO'da başta özel eğitim öğretmeni olmak üzere bağımsız, nitelikli, gönüllü öğretmen görevlendirilmesi istemişlerdir. Veli iş birliği ve düzenli RAM ziyaretleri de önerilmiştir. OY Suat Bey, “...bir öğretmen olsa veya iki ögretmen olsa, kadro açılabilir mesela destek ĕgitim ögrretmeni, özel ĕgitim ögretmenlerimiz var ama mesela normal okullarda da bu olabilir...” diyerek, RÖ Deniz Hanım ise “...Bence çok gerekli bir şey destek eğitim odası ama işleyişinde bazı eksiklikler var. Yani materyal anlamında, yönetici, eğitici anlamında çok büyük eksiklikler var. Özellikle ĕgitim konusunda sınıf ögretmenlerinin değil... Özel ĕgitimcilerin gelip ĕgitim vermesi çok daha mantıklı. Sinıfçılar tek düzeye düşüp yine okuma yazmaya girdiği için destek ĕ̌itim odasının bir amacı ortadan kalkmış oluyor bence..." şeklindeki sözleriyle ideal DEO’da görev yapması gereken kişiyi aktarmışlardır. RÖ Leyla Hanım, veli iş birliğine dikkat çekerek, “... DEO çalışmalarının yani engelli öğrencinin velisiyle birlikte çalışmanın yapılması gerektiğini düşünüyorum ...” şeklinde bu konudaki düşüncelerini açıklamıştır. Öğretmen Füsun Hanım, DEO'da yardımcı personel görevlendirilmesi gerektiğini “...destek eğitim odasında şu anaokullarında olduğu gibi yardımcı birine ihtiyaç var kesinlikle tek kişinin iki öğrenci de olsa tek kişinin yürütebileceği bir iş değil..." sözleriyle aktarmaktadir.

\section{DEO'nun İşleyişine Dair Edinilen Bulgular}

$\mathrm{Bu}$ temada SN'lerin tutulduğu Defne İlkokulunun DEO'larındaki öğretim sürecinden edinilen bulgular, aynı tema altında karşılaştırmalı olarak sunulmuştur. Buradaki amaç öncelikle öğretim sürecini tüm detaylarıyla aktarmak olduğundan katılımcılarının görüşmeleri, resmi dokümanları, ürün dosyalarıyla AG'deki bilgiler detaylı olarak ilgili alt temada belirtilmiştir. Bu başlıkta diğer katılımeı ve ortamlardan elde edilen bulgular yansıtılmamıştır. Tartışma başlığında tüm süreçler birleştirilerek yorumlanmıştır.

Öğretim Öncesi Hazırlık. Her iki durumda ÖGÖ’lerin kişisel dosyaları, BEP’lerle DEO’ya ait dokümanları olduğu anlaşılmıştır. Durum 1'de BEP'lerin nasıl yapıldığı görüntülere şu şekilde yansımıştır: “DEO’nun kapısında rehber öğretmen ile Can ögretmen konuşuyor. Can ögrretmen rehber ögretmene, “3. Grup seslerin ögretimine geçtik. Berrak ögretmenle konuşursanız yeni BEP yapsın ama o daha iyi bilir” diyor. Rehber 
ögretmen, "Berrak Öğretmen'le görüşürüm, iyi dersler" diyor çıklyor." (Görüntü: 19). AG ve gözlemler, veli dışında DEO paydaşlarıyla iş birliği yapıldığını göstermekle birlikte BEP'lerin DEO öğretmeni tarafindan hazırlanmadığını ortaya koymuştur. Ayrıca her iki durumda öğretmenlerin öğretime ilişkin hazırlık çalışmaları yapmadığı; sadece Durum 1'de öğretmenin bir sınıf kuralına yer verdiği gözlemlenmiştir.

DEO'da Öğretim ve Uygulama Süreci. Bu süreçte öğretmenlerin derse farklı şekilde giriş yaptıkları gözlemlenmiştir. Durum 2'de öğretmenin sohbet ederek, hatırlamalar yaparak öğretimi başlattığı görülürken; Durum 1'de öğretim başlatma sürecinde bunlar gözlenmemiştir. Dersi bitirme sürecindeyse öğretmenlerin zamanında dersi bitirdikleri ancak ödevlendirme ve değerlendirme yapmadıkları anlaşılmıştır. $\mathrm{Bu}$ durumun gerekçesi AG’ye şu şekilde yansımıştır: “...Can Öğretmen bugün şunları anlattı: "ödev veriyorum ama hiç yapmiyor. Siz de gördünüz anne yapıyor...”. Öğretmenlerin genellikle öğretimde hata düzeltme, tekrar etme, model olma, dönüt ve yönerge vermeye ilişkin yöntem teknikleri kullandığı, iki öğretmenin de öğretimsel rutinleri olduğu gözlemlenmiştir. Aşağıda Tablo 3'te Durum 1'de okuma-yazmaya öğretimine ilişkin tekrara dayanan rutinle dikte örneği sunulmuştur:

Tablo 3

Durum 1 Okuma Yazma Tekrar Örneği (Görüntü 26)

\begin{tabular}{cccc}
\hline Satır & \multicolumn{1}{c}{ Davranış öncesi } & Davranış & Davranış sonrası \\
\hline 2 & $\begin{array}{l}\text { Öğretmen "annnnnnn ne naaaane } \\
\text { al” diyor. }\end{array}$ & $\begin{array}{c}\text { Eda tahtaya söyleneni } \\
\text { hatasız yazıyor. }\end{array}$ & Öğretmen "Çok güzel! Aferin! Yaz!” diyor. \\
\hline
\end{tabular}

Öğretmenlerin, öğretimsel uyarlamaları sıklıkla kullandığı gözlemlenmiştir. Durum 2'de öğretmenin günlük yaşamdan örnekler vererek gerçekleştirdiği öğretimsel uyarlamalar bulgulara yansımıştır. Füsun Öğretmen öğretimi oyunlaştırarak öğrenciyi derse dâhil etmesini şu şekilde açıklamıştır: “...Bu defa o şehirlerle ilgili küçük cümleler oluşturmaya başladık. Mesela Malatya kayısısıyla ünlüdür. O cümleyi yazdık. Buradaki Malatya kaylsislyla ünlüdür derken Malatya harfinin büyük olduğunu, gelen işte cümleye başlarken büyük harfle başlandı̆̆ını, özel isimlere gelen eklerin kesme işaretiyle ayrıldı̆̆ın ister istemez çocuklar farkında olmadan yani plakalarla zevkli bir şekilde Kemal ile ilgili yaparken Ceren de aynı șekilde eksikliğini Kemal ile beraber Ceren bu șekilde telafi ettik...”.

Füsun öğretmenin açıkladığı öğretimsel uyarlama SN’ye de yansımıştır: “...Kemal plaka söyle” dedi ögretmen. " 40 " dedi Kemal " 42 de Konya benim dediğim olsun" dedi ögretmen. 40 ile 42 'yi topluyor tahtada. Ceren tahtada üst üste toplama yaptı. Kemal yemek yemeye başladı. "Şimdi yemek dersi değil. Yeme, kaldır" dedi ögretmen. "Tamam" dedi Kemal. Öğretmen "82" dedi. 82 nerenin plakası diye tartıştılar..." (SN: 3). Durum 2'de BEP'lerde olmamasına karşın öğretmenin derste öğrencilere empati kurma çalışmaları yaptırdığı; yabancılara karşı kendilerini koruma becerilerinin öğretimine yer verdiği de görülmüştür (bk. Tablo 4).

Tablo 4

Durum 2 Yabancllara Karşı Kendini Koruma Örneği (Görüntü 19)

\begin{tabular}{|c|c|c|c|}
\hline Satır & Davranış öncesi & Davranış & Davranış sonrası \\
\hline 43 & $\begin{array}{l}\text { Öğretmen Ceren’e “bir başkası gelip } \\
\text { seni annene götüreyim ya da çikolata } \\
\text { alayım dese gider misin?” diyor. }\end{array}$ & $\begin{array}{l}\text { Ceren "hayır kandırır kaçırır bizi” } \\
\text { diyor. Kemal "Çünkü tanıdık } \\
\text { değil” diyor. }\end{array}$ & Öğretmen Ceren'e bakıyor. \\
\hline 44 & $\begin{array}{l}\text { Öğretmen "Ne yaparsın diyor? } \\
\text { Ceren'e. }\end{array}$ & $\begin{array}{l}\text { Ceren "Bağırırım" diyor. Kemal } \\
\text { öğretmeni dinliyor. }\end{array}$ & $\begin{array}{l}\text { Öğretmen "Zaten Ceren bir } \\
\text { yumruk attı mı tekme attı mı dün } \\
\text { aşağıda gördüm" diyor. }\end{array}$ \\
\hline 45 & $\begin{array}{l}\text { Öğretmen "Nöbet sırasında yaptığın } \\
\text { hareket çok yanlış" diyor. }\end{array}$ & $\begin{array}{l}\text { Kemal “Dün Ceren'i nasıl } \\
\text { gördün?" diyor. Ceren dinliyor. }\end{array}$ & $\begin{array}{l}\text { Öğretmen "Dün ben nöbetçiydim } \\
\text { o yüzden" diyor. }\end{array}$ \\
\hline
\end{tabular}

Davranış Yönetimi. Öğretmenlerin; uygun olmayan davranışla baş etme ve ortadan kaldırma, uygun davranışı sürdürme, derse aktif katılımı sağlama çabaları SN'ye yansımıştır. Öğretmenlerin uygun olmayan davranışla baş etmede farklı stratejileri kullandıkları, sıklıkla görmezden gelmeye yer verdikleri anlaşılmıștır. Her iki durumda ÖGÖ'lerin DEO'ya geçiş sorunu yaşadıkları, DEO'ya gelmek istemedikleri gözlenmiştir. Özellikle Durum 1'de gözlemlerin başlarında Eda'nın DEO'ya gelmediği ve öğretmenin Eda'yı okulda aramaya gittiği, Eda'nın DEO'ya gelir gelmez hemen ayrıldığı gözlenmiştir. Bu örnek Tablo 5'te sunulmuş̧ur. 
Tablo 5

Durum 1 DEO Geçiş Örneği (Görüntü 17)

\begin{tabular}{|c|c|c|c|}
\hline Satır & Davranış öncesi & Davranış & Davranış sonras1 \\
\hline 1 & $\begin{array}{l}\text { 03.00-Öğretmen araştırmacıya } \\
\text { "gelmedi mi?" diyor sınıftan çıkıyor. }\end{array}$ & Eda DEO'da değil & Öğretmen DEO’da değil \\
\hline 2 & $\begin{array}{l}\text { 07.26-Öğretmen Eda'yla birlikte } \\
\text { sinıfa geliyor. }\end{array}$ & $\begin{array}{l}\text { Eda sınıfa ayaklarını vura vura } \\
\text { gülerek giriyor, elinde içinde } \\
\text { pasta olan tabakla geliyor. }\end{array}$ & $\begin{array}{l}\text { Öğretmen sınıfa giriyor kızarak } \\
\text { "geç şuraya! Geç kızım ya!” diye } \\
\text { sırasını gösteriyor. }\end{array}$ \\
\hline
\end{tabular}

Eda'nın okuma-yazmaya ilişkin verilen akademik sorumlulukları yerine getirmek istemediği anlaşılmıştır. Can öğretmenin, öğrencinin ders öncesi ve süresince sergilediği uygun olmayan tüm davranışları sesle kontrol etme, sözel uyarı, fiziksel yakınlık kurma gibi tekniklerle kontrol altına almaya çabaladığ görülmüştür. Öğretmenin belirtilen bu problem davranışı, ortama akranın katılmasıyla ortadan kaldırdığı gözlemlenmiştir. Bu süreç Tablo 6'daki gibi görüntülenmiştir.

\section{Tablo 6}

Durum 1 Tipik Gelişen Öğrencinin DEO’da Eğitim Alması Örneği (Görüntü 24)

\begin{tabular}{|c|c|c|c|}
\hline Satır & Davranış öncesi & Davranıș & Davranış sonrası \\
\hline 137 & $\begin{array}{l}\text { Öğretmen "bak illa illa } \\
\text { Atilla" diyor. Sonra "Ata ot } \\
\text { at" yazıyor tahtaya, "oku } \\
\text { oku" diyor. }\end{array}$ & $\begin{array}{l}\text { Eda “Ata ot at" diyor, hızlıca tahtaya } \\
\text { gelip yazmaya başlıyor. Eda tahtaya } \\
\text { hem yazıyor hem de ögretmenle tekrar } \\
\text { ediyor ardından yerine oturup hızlıca } \\
\text { defterine yazmaya başliyor. }\end{array}$ & $\begin{array}{l}\text { Öğretmen “okuyarak yazıyoruz" } \\
\text { diyor ve Eda'nın defterine } \\
\text { yazdıktan sonra Tamer “biraz } \\
\text { yamuk olmadı mı?" diyor. }\end{array}$ \\
\hline
\end{tabular}

Durum 2'de neredeyse gözlem sürecinin tamamında Kemal'in derste sıkılma, derse katılmama davranış1 gözlemlenmiştir. Kemal, sadece dersten sıkıldığını söylememekte "Offf...!", "Bıktım!', "Sıkıldım!" gibi ifadelerle sırasına uzanarak uzun süre bir noktaya dalarak dersten kopmaktadır. Bu durum okul BEP Kurulu'nun yaptığı toplantı tutanaklarına da yansımıştır. Füsun öğretmen, dersi oyunlaştırma, etkinlik pekiştireçlerinden dersin sonunda satranç oynamaya izin verme gibi stratejilerle belirtilen davranışların üstesinden gelmeye çalışmıştır. Satranç oynama isteği şu şekilde görülmektedir: “...12.34 Kemal çantası ile geldi. "Ben Ceren'in yanına satranç oynamaya gidecem" dedi, gitti..." (SN: 11). Durum 2'de sistematik bir şekilde sembol pekiştireç uygulaması kullanılmış; uygun olan davranışı sürdürmek adına da sıklıkla sosyal pekiştireçlere birlikte sözsüz onaylamalara da yer verilmiştir. Durum 1'deyse öğretmenin pekiştireçlerle sosyal pekiştireçlere çok az yer verildiği görülmüştür.

Derse aktif katılımı sağlamak için her iki durumda öğretmenlerin ÖGÖ’lerle şakalaştıkları, derse ara vererek sohber ettikleri, öğrencilerin isteğine bağlı etkinlik değiştirdikleri gözlenmiştir. ÖGÖ’yü derslere aktif katılımı sağlamak adına Durum 1'de öğretmenin sözel uyarı vermiş, DEO’ya tipik gelişen akranı dâhil etmiştir. Durum 2'deyse akademik sorumluluk vererek, günlük olaylar hakkında sohbetlerle, akran onaylatmaları ve bireysel öğretim yaparak öğretmenin öğrencilerinin derse aktif olarak katılımı için çaba sarfettiği görülmüştür. Ancak Durum 2'de tüm bu çabalara rağmen uygun olmayan davranışlarda azalma olmamıştır.

DEO’da İletişim ve Etkileşim. SN'lerden edinilen verilerde her iki öğretmenin iletişim özellikleri incelendiğindeyse öğretmenlerin akıcı ve etkili Türkçe kullanımı; sabırlı ve kabul edici olma, empati kurma ve olumsuz durumları tolere edebilme davranışları sergilediği ortaya çıkmıştır. AG’ye bu durum şu şekilde yansitılmıştır: “...Gözlemlere bakıyorum da her iki öğretmen Türkçe ’yi oldukça etkili ve akıcı kullanıyorlar. Can Öğretmen özellikle okuma yazma çalışıyor ve doğru Türkçe kullanımı önem arz ediyor...”. Bu özellik, Durum 1 'de okuma-yazma öğretiminin yapıldığından AG'ye yansıtılmıştır.

\section{Tartışma}

Bu çalışma Doğu Anadolu Bölgesi’nde bir il merkezinde 12 okul ve bu okulların DEO hizmetine katılan paydaşların görüşleriyle sınırlandırılsa da DEO’ya ilişkin farklı veri toplama araçlarından elde edilen bulgularla ayrıntılı bir şekilde bu başlık altında tartışılmıştır.

\section{DEO'nun Fiziksel Ortamı}

Katılımcılar, DEO’nun fiziksel ortamının yetersizlikler olduğunu bildirmişlerdir. Belirtilen eksiklikler KL ile desteklenmiştir. Türkiye'de benzer çalışmalarda bu konuya değinmişlerdir (Akay, 2011; Aydın, 2015; Çağlar, 2016; Dalga, 2019; Filig, 2019; Kaplan, 2019; Pemik, 2017; Pesen, 2019; Talas vd., 2016; Yazıcı̆̆lu, 2020). Destek Eğitim Odası Kılavuzu'nda (MEB, 2016) belirtilmesine rağmen fiziksel ortama ilişkin sorunların 
bildirilmesi DEO’nun işlevselliğini sorgulatır niteliktedir. MEB'in bu eksikliklerin ivedikle önüne geçmesi bu çalışmada tekrar talep edilmektedir.

\section{Paydaş Görüşleri}

Paydaşlar, DEO’ya ilişkin olumlu görüşten ziyade yoğun şekilde yaşanan sorunları aktarmaları bu araştırmanın önemli sonuçları arasındadır. DEO’da görevlendirilen öğretmenlerin DEO bilgi eksikliğinin RÖ ve OY tarafından özellikle bildirilmesi alanyazınla da örtüşmektedir (Dalga, 2019; Filig, 2019; Kaplan, 2019; Kotil, 2019). Paydaşların DEO’da görevlendirilen öğretmenlere ilişkin görüşleri burada neden özel eğitim öğretmeni görevlendirilmesi gerektiğini kanıtlar niteliktedir.

ÖGÖ’lere, genel eğitim ve DEO'da aynı BEP'in uygulanması diğer temel sorunlardandır. Türkiye'de DEO'ya ilişkin yapılan çalışmalarda BEP hazırlama ve uygulama sorunu bildirirken (Akay, 2016; Aslan, 2019; Semiz, 2018); Yazıcıoğlu'nun (2020) çalışmasında öğretmenler BEP hazırlama konusunda görüş dahi bildirmemişlerdir. Bu bulgular, BEP'i işlevsel kullanamayan öğretmenlerin DEO'nun esnek program olmasını da bilmediği ve DEO’yu amacından uzaklaştırdığını da göstermektedir. Bu nedenle sadece DEO öğretmenlerine değil KU kapsamında hizmet sunan tüm öğretmenlere BEP eğitimi verilmesi önerilmektedir.

Katılımcıların çoğu, DEO konusunda veliyle iş birliği yapamadıklarını aktarmışlardır. Bulgular, DEO, iş birliğinin özellikle RÖ’lerin ve yöneticilerin liderliğinde olduğu göstermektedir. Benzer sonuçlar alanyazında da mevcuttur (Yazıcıoğlu, 2020; Yazıcıoğlu, 2019a). Türkiye'de yapılan DEO çalışmalarında, veli öğretmen iş birliği sorununda ortak görüş bildirilerek gerekliliğine vurgu yapılmaktadır (Dalga, 2019; Filig, 2019; Kaplan, 2019; Kotil, 2019; Tamas, 2020; Yazıcıŏglu, 2020; Yazçayır, 2020). Alanyazın bu konuda lideri, DEO öğretmeni olarak belirterek iş birliğini dolaylı rolleri arasında göstermektedir. DEO liderliği, destek ekibi üyeleriyle iş birliği yapma (Council for Exceptional Children [CEC], 2015; Desphande, 2013; düzenli toplantılar yapma, DEO çalışma programı hazırlama (Lott vd., 1975), BEP hazırlama ve uygulama (CEC, 2015) ve bu süreçleri koordine etme (CEC, 2015), DEO öğretmeninin iş birliği kapsamındaki diğer dolaylı sorumluluklarıdır.

DEO öğretmeninin diğer dolaylı rolleri arasında danışmanlık hizmeti kapsamında öğrencinin sınıf ortamında izleme (Meents, 1990), DEO paydaşlarıyla görüşme, öğretmeni motive etme ve öğrenci konusunda bilgi verme (Lamar-Dukes \& Dukes, 2005) de bildirilmektedir. Ancak belirtilen danışmanlık sorumluluklarının hiçbiri bulgulara yansımamıştır. Danışmanlık rollerine ilişkin bulguların ortaya çıkmama nedeni, DEO'da görevlendirilen öğretmenlerin sınıf öğretmeni olmasıdır. Ayrıca böyle bir sorumluluk alanyazından farklı olarak Özel Eğitim Hizmetleri Yönetmeliği'nde (T.C. Resmi Gazete, 2018) de bulunmamaktadır. Bu çalışmada belirtilen bu danışmanlık rol ve sorumlulukların RÖ’ler tarafından yerine getirildiği bu çalışmada ortaya çıkan sonuçlardandır.

Bulgulara bakıldığında, en çok vurgulanan sorunun öğretmen görevlendirmesine ilişkin olduğu görülmektedir. Bu çalışmada DEO'da öğretmen görevlendirme sorunlarının sadece OY ve RÖ’lerden oluşan katılımcılar tarafından değinilmesi dikkat çekicidir. Özel Eğitim Hizmetleri Yönetmeliği (T.C. Resmi Gazete, 2018, Madde 25) ve Destek Eğitim Odası kılavuzu (MEB, 2016) görevlendirme noktasında ölçüt koymuş, görevlendirilecek öğretmenlerin öncelikle bu konuda seminer almış öğretmenlerden oluşmaş gerektiğini vurgulamıştır. Katılımcı özellikleri incelendiğinde bu çalışmaya katılan DEO öğretmenlerin çoğunluğunun DEO’ya ilişkin seminer almayan sınıf öğretmenlerinden oluştuğunu göstermektedir. Aynı sorun Talas ve diğerleri (2016) tarafından da bildirilmiştir. Ayrıca iki öğretmenin gönüllü olarak burada görev yapmaması dikkat çekicidir. Gönüllülük ilkesi KU'nun vazgeçilmezidir. Demirtaş, Arslan ve Güven (2016), özel eğitime ilişkin farklı eğitim ortamlarında kısa süreli eğitimlerle sınıf öğretmeni görevlendirildiğini, bu durumun ciddi öğretimsel sorunlara neden olduğunu ve belirtilen sorunun eğitim alanında "Meslekte esas öğretmenlik" algısından; özel eğitim alanında yeterince öğretmen yetiştirilmemesinden kaynaklandığını ifade etmektedirler. Belirtilen olumsuzluklar, DEO'nun işleyişine zarar vermektedir. Bu bulgular, DEO’da asıl görevlendirilmesi gerekenlerin, özel eğitim öğretmeni olması gerçeğini bir kez daha kanıtlamaktadır ve bunu RÖ ve OY de ideal DEO noktasında aktarmışlardır. Araştırmanın bu sonuçları alanyazınla benzerlik göstermektedir (Yazıcıŏlu, 2019a; Yazıcı̆̆ğlu 2020).

\section{DEO’nun İşleyişine İlişkin Tartışma}

DEO işleyişi bakıldığında ÖGÖ’lerle gerçekleştirilen öğretimlerin başarılı bir şekilde sürdürülmesinin nedeninin öğretmenlerin deneyimleriyle ilişkili olduğu yönündedir. Defne İlkokulunda öğretim öncesi yapılan hazırlık çalışmaları kapsamında DEO öğretmenlerinin, BEP yapmadıkları, BEP’leri öğrencinin sınıf öğretmenlerinden veya RÖ’lerden temin ettikleri görülmektedir. Benzer sonuçlara alanyazında da bildirilmektedir (Yazıcıoğlu 2019a, 2019b, 2020). Edinilen BEP'ler incelendiğindeyse Destek Eğitim Odası Kılavuzu'nda (MEB, 
2016) belirtilen destek hizmete ilişkin detaylı bilgilerin öğrenci BEP'lerinde yer almadığı görülmüştür. Ayrıca Defne İlkokulunda OY ve RÖ’ler, DEO programını birlikte hazırladıkları dile getirilmişlerdir. Bu bulgulardan hareketle DEO hazırlık aşamasında öncelikle yöneticilerin ve RÖ’nün sonrasındaysa BEP geliştirme biriminin sorumluluklarını yerine getirdikleri anlaşılmaktadır. Ancak alanyazın, BEP hazırlama, DEO programı hazırlama ve uygulama sürecinin liderlerinin DEO öğretmenleri olduğu belirtilmektedir (Cohen, 1982). Yapılan gözlemler, DEO öğretmeninin bu sorumluluklarını da yerine getirmediğini ortaya koymaktadır.

Gözlenen DEO’nun kaynaklarda belirtildiği gibi olmaması, sınıf ortamından farksız olması, ÖGÖ’nün DEO'ya gelmek istememesine ve geçiş sorununa neden olduğunu düşündürmektedir. SN'ye yansıyan bu sorun, görüşmeler sırasında paydaşlar tarafından da tekrarlanmıştır. Yapılan çalışmalar da bu sorunları bildirmektedir (Çağlar, 2016; Kotil, 2019; Meyers vd., 1990). Bu noktada bu sorunun olumlu sınıf atmosferi yaratarak, davranışların yönetimi adına rutin oluşturarak ve kurallar koyarak önlenebileceği belirtilmektedir (JMNE, 2006).

DEO’da öğretim ve uygulama süreci, DEO’nun işleyişi sürecine ilişkin önemli bilgiler vermektedir. Öğretmenlerin her iki durumda öğretime ilişkin ciddi çaba sarf ettiği gözlemlenmiştir. Can öğretmenin okumayazma öğretimindeki öğretimsel rutinlerinin, Güzel-Özmen ve Vayiç'in (2007) okuma-yazma öğretimsel basamaklarıyla benzerlik gösterdiği SN'lerden anlaşılmaktadır. Ancak bu araştırmada öğretmen belirtilen çalışmadan farklı olarak aynı ses gruplarıyla değil de değişken ses gruplarıyla çalışmış, az da olsa ilerleme kaydetmiştir. Alanyazın, DEO'da iyileştirici okuma yazma müdahalelerinin başarıyla uygulandığ raporlanmaktadır (Mote, 2010; Williams, 2017). Bu noktada vurgulanması gereken alanyazında belirtilen müdahalelerin özel eğitim öğretmeni tarafından gerçekleştirildiğidir.

Görüşmelerde, öğretmenler öğretimsel uyarlamalara ilişkin bilgi vermemişlerdir. SN'ye dönüldüğündeyse DEO bağlamlarında, her iki durumda öğretimsel uyarlamalara yer verildiği ortaya çıkmaktadır. Alanyazın, sınıf öğretmenlerinin öğretimsel uyarlamalara ilişkin yardım gereksinimlerinin olduğunu bildirmektedir (Stitt, 2010; Vural \& Y1kmış, 2008). DEO öğretmenlerinin de öğretim sırasında sıklıkla öğretimsel uyarlamalara başvurduğu, ancak bu uyarlamaların BEP'lerde yer almadığı görülmüştür. Bu durum özel eğitimin sistematik ve düzenli özel eğitim çalışmalarıyla örtüşmemektedir.

Gözlemler sırasında ikinci durumda BEP'te yer almayan yabancılardan kendini koruma, arkadaşlarına vurmama gibi becerilere ek olarak, empati çalışmalarına dahi yer verildiği anlaşılmaktadır. Bilişsel süreçlerin kullanıldığı bu tür öğretimlerde alanyazında özellikle teknoloji desteğiyle yapılmış çalışmalar dikkat çekmektedir. Yıldırım ve Güven (2012), iki farklı problem durumu karşısında ÖGÖ’lerin empati kurarak problem çözme becerilerini sergilediklerini bildirmişlerdir. Kısacası, DEO'da teknolojinin öğretime çok yönlü olumlu katkı sağlayabileceği, bireysel öğretimleri destekleyebileceği belirtilmelidir.

DEO'da davranış yönetimine ilişkin farklı süreçler yaşanmıştır. Durum 1'de sergilenen uygun olmayan davranışlar ortadan kalkarken; Durum 2'de öğrencilerin uygun olmayan davranışlarında artış gözlenmiştir. Öğretmenler, özel eğitimde yer verilen davranış yönetim bilgisi olmamasına rağmen davranışçı yaklaşımlardan faydalanmışlardır. Bu yaklaşımların kullanımının öğretmenin deneyimleriyle ilişkili olduğu düşündürmektedir. Türkiye'de yapılan DEO çalışmalarında da uygun olmayan davranışlarda azalma (Aydın, 2015; Çağlar, 2016) raporlanırken bir çalışmada artış bildirilmiştir (Semiz, 2018). Alanyazında farklı davranışçı yaklaşıma dayalı olarak DEO'da uygun olmayan davranışların azaltılmasına ilişkin çalışmalar yapıldı̆̆ 1 ve farklı oranlarda başarılı oldukları raporlanmıştır (Puhrmann, 2011; Springer, 2012). Bu durum aslında özel eğitim öğretmenlerinin DEO'da neden olması gerektiğini bir kez daha ortaya koymaktadır.

$\mathrm{Bu}$ çalışmada öğretmenlerin deneyimli öğretmenler olmalarına bağlı olarak öğrencilerin derse aktif katılımını sağladıkları ve tipik gelişen bireylerin DEO’ya çağırılıp öğretime dâhil edilmesi sonrasında uygun olmayan davranışların ortadan kalkmasının tesadüfî olmadığını düşündürmektedir. Durum 1'de gözlenen öğrenci HDZY ve DEHB tanısı almıştır. Motavalli-Mukaddes (2014), DEHB'li bireylerin eğitimlerini yürütürken, ders çalışırken bir kişinin destek olmasının bu bireylerin işlerini kolaylaştırdığını ifade ederek, bu uygulamayı akran koçluğu olarak dile getirmiştir. Araştırmacı, DEHB'li bireylerin öğretim süreçlerinde akran koçluğu uygulanmasına yer verilmesini önermektedir. Bu çalışmada her iki DEO bağlamında akran desteğinin öğretimi olumlu anlamda etkilediği görülmüştür. Hatta bu süreçte Defne ilkokulundan RÖ Deniz Hanım, tipik gelişen öğrencilerin de DEO’dan hizmet alma görüşünü desteklemektedir.

Son olarak öğretmenler, DEO’nun öğretimsel çıktıları kapsamında bilgiler vermişlerdir. Paydaşlar, DEO ve özel eğitim bilgileri olmamasına rağmen öğrencilerde az da olsa ilerleme bildirmişlerdir. Az sayıda öğretmen DEO öğretiminin etkili olmadığını belirtmiştir. Alanyazında DEO’da gerçekleştirilen uygulamalara ilişkin farklı 
sonuçlar raporlanmıştır. DEO'da gerçekleştirilen bazı araştırmalar olumlu öğretimsel çıktıları raporlarken (Khalid \& Anjum, 2019; Ünay, 2012) diğer bir kısmı DEO’da sunulan eğitimin başarısızlığını dile getirmektedir (Swanson \& Vaughn, 2010). Bu çalışmada yurt dışında yapılan çalışmalardan farklı sonuçlar ortaya çıkmıştır. Öğretmenler, DEO'larda genel olarak akademik alanlarda çalışmalarda ilerlemeler kaydettikleri bilgisine ek olarak sosyal beceri, öz bakım gibi alanlarda da gelişmeler olduğunu ifade etmektedirler. Türkiye' de yapılan diğer çalışmalarda da akademik gelişmelerle birlikte benzer alanlarda ilerleme ve uygun olmayan davranışlarda azalma raporlanmaktadır (Aydın, 2015; Filig, 2019; Kaplan, 2019; Sayan, 2019; Tamas, 2020; Ünay, 2012; Yazçayır, 2020; Yazıcıŏlu, 2020).

DEO hizmeti, genel ve özel eğitim sınıfı arasındaki boşluğu dolduran özel eğitim sınıfına alternatif olarak geliştirilen; iyileştirme amaçlayan bir hizmettir (Winter \& Kilpatrick, 1999). Ancak bu çalışmada araştırılan boyutların çok sağlıklı işlemediği ortaya çıkmıştır. Bu işleyişteki bozukluklar SN'ye yansımış, yapılan görüşmelerle de desteklenmiştir. DEO işleyişini, OY ve RÖ’nin iş birliği içinde sürdürdükleri, okulda özel eğitim öğretmenleri olmaması nedeniyle okulların özel eğitim liderlerinin özellikle RÖ’ler olduğu; DEO konusunda ÖGÖ’lerin mağdur olmamaları adına oldukça fazla sorumluluk yüklendikleri anlaşılmıştır.

Kısacası, DEO öğretmeninin özel eğitim öğretmeni olmamasından kaynaklı olarak doğrudan rollerini yerine getirmeye çabaladıkları ancak dolaylı rolleri olan danışmanlık kapsamındaki iş birliği ve koordinasyon sorumluluğunu RÖ’lerin üstlendiğini ortaya çıkmıştır. DEO öğretmenlerinin bu süreçte sadece öğretim yaptıkları, BEP hazırlamadıkları, destek ekibiyle sistemli toplantılar yapmadıkları da anlaşılmıştır. Bu öğretmenlerin, özel eğitim alanındaki eğitim öğretim uygulamalarıyla davranış yönetiminden oldukça uzak geleneksel öğretimler sürdürdüğü, tüm bu olumsuzluklara rağmen ÖGÖ hedeflenen iyileştirmelerin az da olsa gerçekleştirildiği gözlemlenmiştir.

OY'lerin de DEO çalışmalarına liderlik yaptıkları öğretmen görevlendirme noktasında ciddi sorunlar yaşadıkları ve çaresiz kaldıkları her şeye rağmen DEO'ya uyum sağlayacak öğretmenleri seçmeye çalıştıkları ortaya çıkmıştır. Kısacası paydaşların genel anlamda KU ve DEO bilgisinin olmamasının DEO hizmetinin sürdürülebilirliğini olumsuz etkilediği anlaşılmıştır. Ayrıca bu bilgisizliğin DEO’ya ilişkin rol karmaşasına neden olduğu, destek sistemin çok yönlü ekonomik hasar aldığı gözlemlenmiştir. Bu karmaşanın önüne geçmek için ivedilikle özel eğitim öğretmenlerinin DEO'lara atanmasının gerektiği; böylelikle OY'lerin ve RÖ'lerin iş yükleri azaltılarak DEO hizmetinin doğru işlemesinin de sağlanmış olabileceği bu çalışmada öngörülmektedir.

Araştırma sonucunda uygulamaya yönelik DEO’larda özel eğitim öğretmenleri görevlendirilmesi, uluslararası alanyazındaki DEO kılavuzlarının Türkiye şartlarına ve kültürüne uyarlanarak eğitim sisteminde kullanılması, okulların yapım aşamasında DEO hizmetinin sunulabileceği dersliklerin planlanması, eğitim fakültelerinin lisans programlarına özel eğitim öğretmenlerinin danışmanlık rolünün geliştirilmesine ilişkin dersler konularak danışmanlık rollerinin güçlendirilmesi ve mevzuatta özel eğitim öğretmenlerinin danışmanlık rollerinin tanımlanması önerilmektedir. İleriki çalışmalara yönelikse DEO kapsamında gerçekleştirilen bireysel ve küçük grup eğitiminin etkililiğini karşılaştıran çalışmalar gerçekleştirilmesi, özel eğitim sınıfı, DEO hizmeti, özel eğitim danışmanlığı gibi farklı özel eğitim destek programlarının etkililiğini karşılaştıran çalışmalar yapılması, DEO'dan faydalanan ÖGÖ’nün sosyal kabulüne ilişsin akran bilgilendirmesi odaklı farklı yöntemlerin kullanıldığı çalışmalar gerçekleştirilmesiyle ÖGÖ’lerin güvenlik becerileri kapsamına giren kendini yabancılara karşı koruma becerisi gibi becerilerin farklı bilimsel yöntemlerle öğretildiği çalışmaların gerçekleştirilmesi önerilmektedir.

Katılımcılar, DEO’da görevlendirilen ayrı bir öğretmen olmaması nedeniyle ÖGÖ’yü ders saatinde DEO’ya göndermemelerini bir sorun olarak bildirmişlerdir. DEO’nun Özel Eğitim Hizmetleri Yönetmeliği'nde (T.C. Resmi Gazete, 2018, Madde 25), BEP biriminin kararına bağlı DEO'da derslerin hafta sonu veya okul ders saati dışında yapılabileceği belirtilmektedir. Ancak yönetmelik maddesinde belirtilen bu uygulama, DEO hizmetinin bileşenleriyle çelişmektedir. DEO hizmeti, ÖGÖ’lerin okuldaki derslerin belli oranında dersten alma uygulaması olarak bildirilmektedir (Wogamon, 2013). ÖGÖ, DEO hizmetiyle dersten alınarak okul ortamından kopmamakta, KU sürdürülmektedir. Sadece Poon-McBrayer (2004), ders saati dışında eğitim verildiğine ilişkin bilgi vermekte; bunu dersten alma uygulaması olarak nitelendirmemekte, belirtilen uygulamanın DEO hizmeti olmadığının altını çizmektedir. Dolayısıyla ilgili uygulama maddesinin tekrar gözden geçirilmesi önerilmektedir.

OY'leri, DEO için; fiziksel alan, finansal kaynak sağladıklarını bildirmişlerdir. Yöneticiler, DEO çalışmalarına ilk olarak fiziksel alan sağlayarak başladıklarını sonrasında donanım ve materyal temin etmeye çalıştıklarını belirtmişlerdir. Bu çalışmada OY'nin çok azı özellikle fiziksel alan sağlamada sorun yaşadıklarını ifade etselerde bu konunun ivedilikle çözüm istemişlerdir. Ülkemizde bildirilen en büyük sorunlardan biri de okulların fiziksel alan sağlanmasına ilişkindir. Bu nedenle derslik sorunu genel olarak çözüm beklemektedir. 
DEO denetlemesine ilişkin yöneticiler farkı bilgiler vermişlerdir. Yöneticiler, DEO’nun öğretimsel çıktılarından bahsederek bir tür denetleme yaptıklarını dile getirmişlerdir. Türkiye'de denetim olarak adlandırılan süreç yurt dışında yapılan çalışmalarda izleme ve değerlendirme olarak ifade edilmektedir. Yöneticilerin, ÖGÖ’lerin eğitim sürecini izleme ve değerlendirmesinin farklı amaçları bulunmaktadır. Bunlar, çalışmaların etkili olup olmadığını izlemek, gerek görüldüğünde uyarlamalar yapmak için çalışmak (Franklin, 2012); ÖGÖ’nün başarısını değerlendirme ve uygulanan program başarısızsa tekrar program geliştirmek (Parker, 2016); düzenli olarak özel eğitim süreçlerini gözden geçirerek en az kısıtlayıcı ortamda gerek görüldüğünde doğru hizmet sunmayı sağlamak (Collins, 2008) olarak belirtilmiştir. Dolayısıyla yöneticilerin bu çalışmada öğrenci adına alanyazınla örtüşen bir amaca hizmet ettiği söylenebilir. Alanyazında belirtilen bir diğer yönetici sorumluluğuysa DEO çalışma programının hazırlanmasıdır (Conner, 2012; Hanley, 2016). Ancak bu çalışmada böylesi bir sonuca net bir şekilde ulaşılamamıştır.

$\mathrm{Bu}$ çalışmada DEO konusunda en kritik ve önemli rolleri ve hatta DEO liderliğini üstlenen paydaşların RÖ olduğu sonucuna varılmıştır. RÖ’ler, DEO paydaşlarının rollerinin net olmamasından kaynaklı olarak DEO hizmetinin liderliğini üstlendiği, öte yandan geleneksel sorumluluklarını da sürdürdükleri anlaşılmıştır. RÖ’ler, DEO konusunda BEP hazırlama dâhil olmak üzere oldukça fazla sorumluluk aldıklarını, bu durumdan rahatsızlık duyduklarını ortak görüş olarak aktarmışlardır. Yazıcıoğlu (2019a) tarafından da benzer sonuçlar bildirilmektedir. Özel Eğitim Hizmetleri Yönetmeliği'nde (T.C. Resmi Gazete, 2018, Madde 47) RÖ’lerin görevi “BEP geliştirme biriminin doğal üyesi” olarak tanımlanmaktadır. Ayrıca Destek Eğitim Odası kılavuzu (MEB, 2016), DEO hizmeti alacak öğrencilerin RÖ’nün de üyesi olduğu Rehberlik ve Danışma Hizmetleri Yürütme Kurulu tarafından belirleneceği ifade etmiştir. Kısacası RÖ’ler, tüm çalışmalarda DEO ekibinin doğal üyesi olarak karşımıza çıkmaktadır (Desphande, 2013). Alanyazın, DEO öğretmeni (Lott, vd., 1975) ve OY'yi (Franklin, 2012) başarılı DEO hizmetini sunmada anahtar kişi olarak bildirmektedir. Ancak bu çalışmada RÖ’lerin, DEO hizmetinin anahtar kişisi olduğunu ortaya çıkmıştır.

Bu çalışmada RÖ’ler, DEO’ya ilişkin yaptıkları çalışmaların arasında destek ekip üyelerine bilgilendirme yapma olduğunu belirtmişlerdir. Bu sonuç alanyazınla benzerlik göstermektedir. Alanyazın BEP birimi üyelerine bilgilendirme yapma söz konusu olduğunda RÖ’lerin özellikle davranış problemleri konusunda öğretmenlere (Desphande, 2013 Engelbrecht, 2004); kaynaştırma ortamlarında veliye bilgilendirme yaparak destek olduğunu (Berger, 2013; Castillo, 2016) raporlamaktadır. Ayrıca bu çalışmada RÖ’ler, koordinatörlük yapmanın yanı sıra DEO hakkında ekibe (Berger, 2013; Engelbrecht, 2004), ÖGÖ’ye (Farrell, 2006), öğretmenlere (Berger, 2013), ÖGÖ'nün sinıf arkadaşlarına (Farrell, 2006) destek verdiklerini de ifade etmişlerdir. Bu noktada özellikle vurgulanması gereken DEO’dan faydalanan ÖGÖ’nün sınıf arkadaşlarının bilgilendirilmesinin, öğrencinin sosyal kabulünü sağlamak adına önemli olduğudur.

Alanyazın RÖ’lerin, DEO kapsamında ÖGÖ’ye danışmanlık yapma ve danışmanlık programı geliştirerek bireysel ve grup danışmanlığı yapma, uygulama, değerlendirme çalışmalarına yer verdiklerini bildirmektedir (Castillo, 2016; Engelbrecht, 2004). Bu çalışmada belirtilen uygulamalara ilişkin herhangi bir bilgiye ulaşılamamıştır. Ancak danışmanlık sürecinin sistematik ve düzenli yapılması gerektiği düşünülürse RÖ’nin, BEP geliştirme birimiyle DEO’ya ilişkin düzenli toplantılar yaptığı ve DEO'ya yönelik sıklıkla değerlendirme çalışmalarına yer verdiği bulgularından hareketle kısmen sistematik bir danışmanlık süreci uygulandığı söylenebilir.

Bu çalışmada görüşmeler sırasında Füsun öğretmenden ideal DEO için DEO'da yardımcı personel çalıştırma önerisi gelmiştir. Yardımcı personel, eğitim ortamlarında öğretimsel destek veren yardımcı yetişkindir (Austin, 2013). Yurt dışında yapılan çalışmalar DEO öğretmenine yardımcı personelin öğretimde destek verdiği bildirilmiştir (PoonMcBrayer, 2004; Wigstrom, 2015). Türkiye'de yapılan çalışmalarda DEO'da yardımcı personel talep edildiğine ilişkin doğrudan bulgulara ulaşılamasa da özel eğitim alanında yapılan çalışmalar yardımcı personelin bu alanda önemine değinmektedirler (Görgün, 2013; Yazıcıŏlu, 2017).

Bir başka ideal DEO önerisi, özellikle RÖ ve yöneticilerden oluşan katılımcılardan gelmiştir. Katılımcılar, DEO'da özel eğitim öğretmeninin görevlendirilmesini istemektedirler. Alanyazın DEO'da özel eğitim öğretmeni görevlendirilmesini çözüm olarak talep etmektedirler (Aydın, 2015; Semiz, 2018). Katılımcılar, tipik gelişen öğrencilerin de buradan hizmet almasını istemekte ve DEO'da küçük grup eğitimi olmasını da önermektedirler. Alanyazında benzer öneriyi destekleyen çalışmalar mevcuttur (Blackford, 2010; Yazıcıoğlu, 2018). 


\section{Kaynaklar}

Akay, E. (2011). Kaynaştırma ortamındaki işitme engelli ilköğretim öğrencilerine sunulan destek ĕ̌itim odası sürecinin incelenmesi [An examination of the process of the resource room application desinged for the mainstreamed primary school aged hearing impaired students] (Tez Numaras1: 298173) [Doktora tezi, Anadolu Üniversitesi]. Yükseköğretim Kurulu Ulusal Tez Merkezi.

Akay, E. (2016). Kaynaştırma ortamında ĕgitim alan işitme engelli öğrencilere destek özel ĕ̆itim hizmeti sunan eğitimciye yönelik mentörlük sürecinin incelenmesi [An investigation of the mentorship process for educators who provide special education support services for hearing-impaired students inclusive education] (Tez Numarası: 425505) [Yüksek lisans tezi, Anadolu Üniversitesi]. Yükseköğretim Kurulu Ulusal Tez Merkezi.

Aslan, S. T. (2019). Kaynaştırma eğitimine devam eden işitme yetersizliği olan ögrencilere verilen destek ĕ̆itim hizmetlerinin ögretmen görüşlerine göre değerlendirilmesi [Evaluation of the support education services provided to the hearing impaired students continuing the inclusive ducation according to the teachers' opinions] (Tez Numaras1: 571499) [Yüksek lisans tezi, Necmettin Erbakan Üniversitesi]. Yükseköğretim Kurulu Ulusal Tez Merkezi.

Austin, K. M. (2013). Training needs of paraprofessionals supporting students with autism spectrum disorders [Doctoral dissertation, Virginia Commonwealth Univesity]. https://scholarscompass.vcu.edu/etd/3056

Aydın, A. (2015). Zihinsel yetersizliğe sahip öğrencilere destek ĕ̆itim odasında verilen eğitim hizmetlerine ilişkin ögretmen görüşleri [Teacher's opinions regarding the instruction service provided to mentally disabled students in the resourceroom] (Tez Numarası: 394745) [Yüksek lisans tezi, Abant İzzet Baysal Üniversitesi]. Yükseköğretim Kurulu Ulusal Tez Merkezi.

Batu, S. (2000). Kaynaştırma, destek hizmetleri ve kaynaştırmaya hazırlık etkinlikleri [Inclusion, support services as preparation activities for inclusion]. Ankara Üniversitesi Ĕgitim Bilimleri Fakültesi Özel Ĕgitim Dergisi, 2(4), 35-45. https://doi.org/10.1501/Ozlegt_0000000050

Baumgartner, M. M. (1979). Generalization of improved subtraction regrouping skills from resource rooms to the regular class: The results of small group intervention (Publication No. 8008970) [Doctoral dissertation, University og Illinois at Urbana-Champaign]. ProQuest Dissertations and Theses Global.

Berger, M. (2013). The role of the educational psychologist in supporting inclusion at school level [Master's thesis, University of Pretoria]. http://hdl.handle.net/2263/40459

Blackford, S. C. (2010). Knowledge and perceptions of students with disabilities in regard to a resource room in a private school [Master's thesis, Cedarville University]. https://files.eric.ed.gov/fulltext/ED525508.pdf

Castillo, J. H. (2016). A multivariate exploraiton of school counselor engagement with students with disabilities [Doctoral dissertation, Syracuse University]. https://surface.syr.edu/etd/

Cohen, J. H. (Ed.). (1982). Handbook of resource room teaching. An Aspen Publishers.

Collins, K. S. (2008). Principals' knowledge of idea and their implementation of special education services [Doctoral dissertation, University of Southern Mississippi]. https://aquila.usm.edu/dissertations/1176/

Conner, M. R. (2012). Special education “preparation gap” perceptions of the western region special education advisers concerning Pennsylvania's special education competencies for school leaders (Publication No. 3503735) [Doctoral dissertation, Indiana University of Pennsylvania]. ProQuest Dissertations and Theses Global.

Council for Exceptional Children. (2015). Ethical principles and practice standards. https://exceptionalchildren.org/standards/ethical-principles-and-practice-standards

Çağlar, N. (2016). Illköğretim kurumlarındaki destek eğitim odası uygulamasına ilişkin okul yöntecileri ve ögretmenlerin görüslerinin incelenmesi [The examing of the opinions of the school managers and reachers "resource education room" in primary education] (Tez Numaras1: 461526) [Yüksek lisans tezi, Gazi Üniversitesi]. Yükseköğretim Kurulu Ulusal Tez Merkezi. 
Dalga, R. A. (2019). Destek ĕgitim odasında görev alan ögretmenlerin özel ögrrenme güçlüğ̈̈ olan öğrencilerle yaptıklarl ĕgitim ögretime ilişkin görüş ve önerileri [Experiences and reccomendations of remediation teachers on teaching students with specific learning disability] (Tez Numaras1: 560502) [Yüksek lisans tezi, Marmara Üniversitesi]. Yükseköğretim Kurulu Ulusal Tez Merkezi.

Demirtaş, H., Arslan, M., \& Güven, D. (2016). Özel eğitim okullarının yönetimsel sorunları [Administrative problems of special education schools]. E-International Journal of Educational Research, 7(1), 21-49. https://doi.org/10.19160/e-ijer.43400

Desphande, A. A. (2013). Resource room in mainstream schools. International Journal of Education and Psychological Research, 2(2), 86-91. http://ijepr.org/panels/admin/papers/35ij16.pdf

Engelbrecht, P. (2004). Changing roles for educational psychologists within inlusive education in South Africa. School Psychology International, 25(1), 20-29. https://doi.org/10.1177/0143034304041501

Farrell, P. (2006). Developing inclusive practices among educational psychologists: Problems and possibilities. European Journal of Psychology of Education, 21(3), 293-304. http://www.jstor.org/stable/23421609

Filig, R. (2019). Sınıf ögretmenlerinin destek eğitim odaları hakkındaki görüşlerinin belirlenmesi [Determination of primary scholl teachers' view about resource room] (Tez Numaras1: 572470) [Yüksek lisans tezi, Necmettin Erbakan Üniversitesi]. Yükseköğretim Kurulu Ulusal Tez Merkezi.

Franklin, C. (2012). Perceptual study of school principals' working knowledge of special education and school' level of educational services (Publication No. 3548324) [Doctoral dissertation, Capella University]. ProQuest Dissertations and Theses Global.

Görgün, B. (2013). Sinıfinda özel gereksinimli öğrenci olan okul öncesi öğretmen yardımclsının rol ve sorumluluklart hakkındaki görüşleri [Opinions of teachers who have inclusion studetns in their classrooms about roles and responsibilities of teacher aids] (Tez Numaras1: 356619) [Yüksek lisans tezi, Anadolu Üniversitesi]. Yükseköğretim Kurulu Ulusal Tez Merkezi.

Güzel-Özmen, R., \& Vayiç, Ş. (2007). Oku-altını çiz-böl-birleştir stratejisinini zihinsel engelli öğrencilerin hece tanıma becerilerinin kazanmalarında etkililiği [The effectiveness of the read-underline-segment-blend strategy on the acquisition of syllable recignition skiss of students with mental retardation]. Ankara Üniversitesi Ĕ̈itim Bilimleri Fakültesi Özel Ĕgitim Dergisi, 8(2), 1-18. https://doi.org/10.1501/Ozlegt_0000000116

Hanley, T. (2016). Principals' experiences with special education (Publication No. 3703541) [Doctoral dissertation, Northeastern University]. ProQuest Dissertations and Theses Global.

Jamaica Ministry of National Education. (2006). Resource manuel for teachers of students with exceptionalities. https://www.mona.uwi.edu/cop/sites/default/files/resource/files/Special\%20Ed\%20Manual.pdf

Kaplan, Ö. (2019). Kaynaştırma okullarındaki özel gereksinimli bireylere destek ĕgitim osasında eğitim veren ögretmenlerin süreç içerisinde karşılaştıklarl güçlüklerin belirlenmesi [Determining the difficulties faced by the teachers who provide education in the support training room for individuals with special needs in inclusive schools] (Tez Numarası: 562110) [Yüksek lisans tezi, Necmettin Erbakan Üniversitesi]. Yükseköğretim Kurulu Ulusal Tez Merkezi.

Khalid, M., \& Anjum, G. (2019). Use of remedial teaching approaches for dyslexic students: Experiences of remedial teachers working in urban Pakistan. Cogent Psychology, 6(1), 1-18. https://doi.org/10.1080/23311908.2019.1580181

Kotil, B. E. (2019). Destek eğitim odası uygulamalarının ve fiziki koşullarının incelenmesi [Investigation of the applications and physical conditions of resource room] (Tez Numaras1: 603359) [Yüksek lisans tezi, Akdeniz Üniversitesi]. Yükseköğretim Kurulu Ulusal Tez Merkezi.

Lamar-Dukes, P., \& Dukes, C. (2005). Consider the roles and responsibilities of the inclusion support teacher. Intervention in School and Clinic, 40(1), 55- 61. https://doi.org/10.1177/10534512050410011501

Lott, L. A., Hudak, B. J., \& Sheetz, J. A. (1975). Strategies and techniquies for maiinstreaming: A resource room handbook. Moure Country Internadiate School District. 
Meents, C. K. (1990). Literarcy instruction in high school resource rooms (Publication No. 9119155) [Doctoral dissertation, State University of NewYork]. ProQuest Dissertations and Theses Global.

Meyers, J., Gelzheiser, L., Yelich, G., \& Gallagher, M. (1990). Classroom, remedial and resource teachers' view of pullout programs. The Elementary School Journal, 90(5), 532- 545. https://doi.org/10.1086/461631

Milli Eğitim Bakanlığı [Ministry of National Education]. (2016). Destek eğitim odası kılavuzu [Resource room guide].

https://orgm.meb.gov.tr/meb_iys_dosyalar/2016_08/03045051_destek_egitim_odasi_kilavuz.pdf

Motavalli-Mukaddes, N. (2014). Otizm Spektrum Bozuklukları tanı ve takibi [Autism Spectrum Disorders diagnosis and monitoring]. Nobel Tip Kitabevi.

Mote, S. Y. (2010). Does setting affect achievement of students with disabilities: Comparing co-teaching to resource [Doctoral dissertation, Liberty University]. https://digitalcommons.liberty.edu/cgi/viewcontent.cgi?article=1419\&context=doctoral

Özel Eğitim Hizmetleri Yönetmeliği [Special Education Services Regulation]. (2018). T.C. Resmi Gazete, (30471), 7 Temmuz 2018. https://www.resmigazete.gov.tr/eskiler/2018/07/20180707-8.htm

Özel Eğitim Hizmetleri Yönetmeliği [Special Education Services Regulation]. (2012). T.C. Resmi Gazete, (28363), 21 Temmuz 2012. https://www.resmigazete.gov.tr/eskiler/2012/07/20120721-10.htm

Özel Eğitim Hizmetleri Yönetmeliği [Special Education Services Regulation]. (2000). T.C. Resmi Gazete, (23937), 18 Ocak 2000, 418- 468. https://www.resmigazete.gov.tr/arsiv/23937_1.pdf

Parker, M. S. (2016). A phenomenological study of the roles of principals in special education [Doctoral dissertation, Walden University]. http://scholarworks.waldenu.edu/dissertations

Pemik, K. (2017). Özel yetenekli öğrencilere destek odasında verilen eğitime ilişkin okul yöneticilerinin ve ögretmenlerin görüsleri [The views of the school administrators and teachers on the education given to gifted students in the support room] (Tez Numarası: 490674) [Yüksek lisans tezi, Marmara Üniversitesi]. Yükseköğretim Kurulu Ulusal Tez Merkezi.

Pesen, H. (2019). Destek eğitim odası uygulamalarına ilişkin öğretmen görüşlerinin incelenmesi [Teachers' opinions on support room applications] (Tez Numaras1: 574000) [Yüksek lisans tezi, Siirt Üniversitesi]. Yükseköğretim Kurulu Ulusal Tez Merkezi.

Poon-McBrayer, K. F. (2004). To integrate or not to integrate: Systemic dilemmas in Hong Kong. The Journal of Special Education, 37(4), 249-259. https://doi.org/10.1504/IJLC.2016.081616

Poon-McBrayer, K. F. (2016). Resource room model for inclusive education in China: Practitioners' conceptual isation and contextualisation. International Journal of Learning and Change, 8(3/4), 317-331. https://doi.org/10.1504/IJLC.2016.081616

Puhrmann, M. (2011). The effects of using the countoons behavior management strategy with young children in an early childhood special education setting (Publication No. 3457326) [Doctoral dissertation, University of South Dakota]. ProQuest Dissertations and Theses Global.

Robbins, A. S. (2014). Experiences of general education elemantry inclusion co-teachers in successful schools: A phenomenological study [Doctoral dissertation, Liberty University]. https://digitalcommons.liberty.edu/cgi

Sabbah, S., \& Shanaah, H. (2019). The efficiancy of resource rooms for special needs in government schools from head masters and teachers of resource rooms and educational counselors perspective. An Najah University Journal for Research, 24(8), 2187-2226. https://doi.org/20.500.11888/2800

Saxon, K. M. (2007). Integrating students with disabilities in to the general education classroom: An ethnographic study on two service delivery models (Publication No. 3302804) [Doctoral dissertation, Boston College]. ProQuest Dissertations and Theses Global. 
Sayan, A. (2019). Destek ĕgitim odalarında ĕ̆itim alan okul öncesi kaynaştırma öğrencilerinin gelişimlerinin incelenmesi [Examination of the development of preschool inclusion students getting education in support training rooms] (Tez Numaras1: 577243) [Yüksek lisans tezi, İstanbul Sabahattin Zaim Üniversitesi]. Yükseköğretim Kurulu Ulusal Tez Merkezi.

Semiz, N. (2018). Özel gereksinimli öğrencilere yönelik destek ĕğtim odası uygulamalarına ilişkin öğretmen ve aile görüşlerinin belirlenmesi [Identifying the teacher and family views on resource rooms practices aimed at students with special needs] (Tez Numaras1: 51109) [Yüksek lisans tezi, Bolu İzzet Baysal Üniversitesi]. Yükseköğretim Kurulu Ulusal Tez Merkezi.

Springer, B. J. (2012). "Superheroes in the resource room": A study examining implemention of the super hero social skills program by a resource teacher with students with externalizing behavior problems (Publication No. 3503252) [Doctoral dissertation, The University of Utah]. ProQuest Dissertations and Theses Global.

Stitt, D. M. (2010). Special education for general education teachers in U.S. accredited schools abroad (Publication No. 3426936) [Doctoral dissertation, Fielding Graduate University]. ProQuest Dissertations and Theses Global.

Swanson, E. A., \& Vaughn, S. (2010). An observation study of reading instruction provided to elementary students with disabilities in the resource room. Psychology in the Schools, 75(5), 481-492. https://www.meadowscenter.org/files/resources/swanson_2010.pdf

Talas, S., Kaya, F., Yıldırım, N., Yazıcı, L., Nural, H., Çelebi, İ., Keskin, Ş., Söylemez, T., \& Nugay, E. (2016). Destek eğitim odaları ve öğretmenler üzerine betimsel bir çalışma: Tokat ili örneği [A descriptive study on resource room and teachers: Tokat Sample]. Journal of European Education, 6(3), 31-52. http://eu-journal.org/index.php/JEE/article/view/13/13

Tamas, G. (2020). Sınıf öğretmenlerinin ve velilerinin destek eğitim odası uygulamalarına ilişkin görüşleri [Classroom teachers and parents views about the resource room special education support services] (Tez Numarası: 254770) [Yüksek lisans tezi, Bayburt Üniversitesi]. Yükseköğretim Kurulu Ulusal Tez Merkezi.

Ünay, E. (2012). Bireysel destek ĕgitimin kaynaştırma öğrencilerinin matematik başarıları ve özyeterlilik algıları üzerine etkileri [Investigation of the effect of support room education in primary schools of the students in Turkish and mathematic sources] (Tez Numaras1: 313082) [Doktora Tezi, Dokuz Eylül Üniversitesi]. Yükseköğretim Kurulu Ulusal Tez Merkezi.

Vural, M., \& Yıkmış, A. (2008). Kaynaştırma sınıfı öğretmenlerinin öğretimin uyarlanmasına ilişkin yaptıkları çalışmaların belirlenmesi. Abant İzzet Baysal Üniversitesi Ĕ̈itim Fakültesi Dergisi, 8(2), 141-159. http://dergipark.org.tr/tr/pub/aibuefd/issue/1495/18090

Watson, S. (2018). Introduction to special education resource room. https://www.thoughtco.com/specialeducation-resource-room-3110962

Wigstrom, Z. D. (2015). Perceptions of special education paraprofessionals in the inclusive and self contained settings [Doctoral dissertation, The University of Vermont]. https://corescholar.libraries.wright.edu/ejie

Williams, A. E. (2017). The effects of multi sensory phonics instruction on the fluency and decoding skills of students with learning disabilities in a middle school resource classroom [Master's thesis, Rowan University]. https://rdw.rowan.edu/etd

Winter, E. C., \& Kilpatrick, R. (1999). The resource role in special education. Irish Educational Studies, 18(1), 180-190. https://doi.org/10.1080/0332331990180118

Wogamon, L. S. (2013). Examininig the relationships between secondary general education teachers' attitudes toward inclusion, professional development, and support from special education personnel [Doctoral dissertation, Liberty University]. https://digitalcommons.liberty.edu/cgi/viewcontent.cgi?article=1820\&context=doctoral 

BİR DURUM ÇALIŞMASI

Yazçayır, G. (2020). Özel gereksinimli ögrencilere yönelik destek eğitim odası uygulamalarının incelenmesi [Investigation of implementations on resoruce room for students with special needs] (Tez Numaras1: 624450) [Doktora tezi, Anadolu Üniversitesi]. Yükseköğretim Kurulu Ulusal Tez Merkezi.

Yazıcıŏlu, T. (2017). Özel gereksinimli bireylerin eğitimde yardımcı öğretmenlik uygulamaları [Asisited teaching practices in the traning of individuals with special needs]. Sinırsız Eğitim ve Araştırma Dergisi, 2(3), 21-33. https://dergipark.org.tr/en/download/article-file/365030

Yazıcıoğlu, T. (2018). Tersine kaynaştırma modeli ve uygulama örnekleri [The reverse inclusion model and practice examples]. Journal of International Social Scineces Education, 4(1), 39-48. https://dergipark.org.tr/en/download/article-file/493342

Yazıcıoğlu, T. (2019a). Rehberlik öğretmenlerinin bireyselleştirilmiş eğitim programı (BEP) biriminin işleyişine ilişkin görüşleri [The opinions of guidance teachers about funvtioning of unit of individualized education program]. Anemon Muş Alpaslan Üniversitesi Sosyal Bilimler Dergisi, 7(5), 225-234. https://doi.org/10.18506/anemon.520753

Yazıcıoğlu, T. (2019b). Risk grubundaki öğrenciler için sınıf öğretmenlerinin yaptı̆̆ı uyarlamalar ve okul rehberlik servisi ile iş birliğine ilişkin rehberlik öğretmenlerinin görüşleri [The opinions of guidence teachers about pravtices in class made by class teachers about the students who are condidered with special needs]. Nevşehir Hacı Bektaş Veli Üniversitesi Sosyal Bilimler Enstitüsü Dergisi, 9(2), 410-425. https://dergipark.org.tr/en/download/article-file/910474

Yazıcıoğlu, T. (2020). Destek eğitim odalarında görev yapan öğretmenlerin destek eğitim odalarının işleyişine ilişkin görüşleri [The opinions of the teachers who work in resource rooms about resource rooms practices]. Ankara Üniversitesi Ĕ̈itim Bilimleri Fakültesi Özel Eğitim Dergisi, 21(2), 299-327. https://doi.org/10.21565/ozelegitimdergisi.584392

Yıldırım, Y., \& Güven, D. (2012). Değerler ölçütleri kapsamında özel eğitim sınıf öğrencilerinin bedensel engelli bireyler hakkındaki görüş ve tutumları [In the context of value criteria, special education class students' opinion and attitude about physically handicapped people]. Kuram ve Uygulamada Eğitim Bilimleri, 12(2), 1475-1490. https://www.researchgate.net/profile/Yusuf_Yildirim6/publication/340579415 


\section{Ankara University Faculty of \\ Educational Sciences Journal of \\ Special Education}

$2021,22(4), 895-919$
RESEARCH

Recieved Date: 04.05.20

Accepted Date: 23.02.21

OnlineFirst: 11.03 .21

\title{
A Case Study for Resource Room Service Attended by Students with Intellectual Disability*
}

\author{
Didem Güven iD 1
}

\begin{abstract}
Introduction: Although it is included in the legislation, the resource room (RR) service within the scope of inclusive practices has recently been provided in Turkey. However, the question of how this service is offered remains controversial.

Method: Therefore, the present study was carried out as a nested single case study, one of the qualitative research methods. The aim was to see and describe how the fundamental dimensions of RR including management, guidance, and implementation as a whole were in effect. Accordingly, semi-structured interviews were conducted with 10 school principals, 10 guidance counselors, and 10 RR teachers. Checklists developed for the physical environment of the RR were used in the schools of the participants. Besides, the researcher took field notes at two separate RRs of a school to describe the functioning of the RR and reflected her views in the diary throughout the process.
\end{abstract}

Findings: As a result of the analysis, three themes were revealed and these included the physical environment, stakeholders' views, and the functioning of the RR. The study revealed that the physical environments of the RRs were insufficient, the counselors and administrators were the leaders of the RR process, and only teaching service was provided with a lack of consultancy service in the RR. It was seen that the participants' knowledge of the RR was insufficient.

Discussion: As a result of the research, it was revelad that the RR service processes did not function properly and the participants did not have enough information about the RR. It has been determined that the teachers only teach in the RR and that the leaders of the RR are the GC and school principals in the schools. It has been suggested to provide special education teachers to the RR in order to regulate these ineligible situations.

Keywords: Inclusive practices, resource room, intellectual disability, school principal, guidance counselor, resource room teacher.

To cite: Güven, D. (2021). A case study for resource room service attended by students with intellectual disability. Ankara University Faculty of Educational Sciences Journal of Special Education, 22(4), 895-919. https://doi.org/10.21565/ozelegitimdergisi.731858

\footnotetext{
*This reseach is based on the doctoral dissertation of the author. It was presented as an oral presentation at the $29^{\text {th }}$ National Special Education Congress.

${ }^{1}$ Corresponded Author: Assist. Prof., Istanbul Sabahattin Zaim University, E-mail: didem.guven@izu.edu.tr, http://orcid.org/0000-0002-5388-6963
} 


\section{Introduction}

The resource room (RR) refers to a comprehensive service model and a type of support that fills the gap between general and special education. It is provided by a teacher assigned to the RR service. RR service is more than a place where the students with special needs (SWSN) are located (Robbins, 2014). Therefore, the main function of the $R R$ is to make improvements by performing individualized interventions in one or more areas such as daily life and social skills and behavioral problems as well as academic fields such as mathematics and literacy according to the needs of the students with special needs (Robbins, 2014; Watson, 2018). The components of RR service include the physical environment consisting of physical conditions, materials, and equipment along with the stakeholders with different roles and responsibilities. The roles and responsibilities of the school principals (SP), guidance counselor (GC), and the teachers assigned to the RR and their physical environments were investigated in this study.

Along with the initiation of the RR service, different studies were conducted on the subject. Baumgartner (1979) investigated the generalization of subtraction skills which were taught in small groups in the RR service, in the general education class. The study determined that teaching in small groups was effective. Saxon (2007) investigated the adaptation process of students with intellectual disability (ID) to the general education class with an ethnographic case study and concluded that it would not be difficult for SWSN to adapt to general education classes regardless of their inadequacy, as long as the conditions and capacity of the school were appropriate.

The present study aims to identify the physical conditions and functioning of the RR by receiving the opinions of the teachers, SCs, SPs. For this purpose, the answers to the following questions were sought:

1. What are the opinions of SPs regarding the RR service, roles, and responsibilities?

2. What are the views of SCs regarding the RR service, roles, and responsibilities?

3. What are the opinions of teachers assigned to RR regarding the RR service, roles, and responsibilities?

4. What are the physical conditions of RR?

5. How does the RR work?

6. What are the contributions of RR to SWSN?

\section{Method}

\section{Research Model}

The study was designed as a nested single state pattern since it was designed as two separate layers consisting of different teachers and students in two terms as presented in the Figure 1.

\section{Figure 1}

The Nested Single Case Study Design

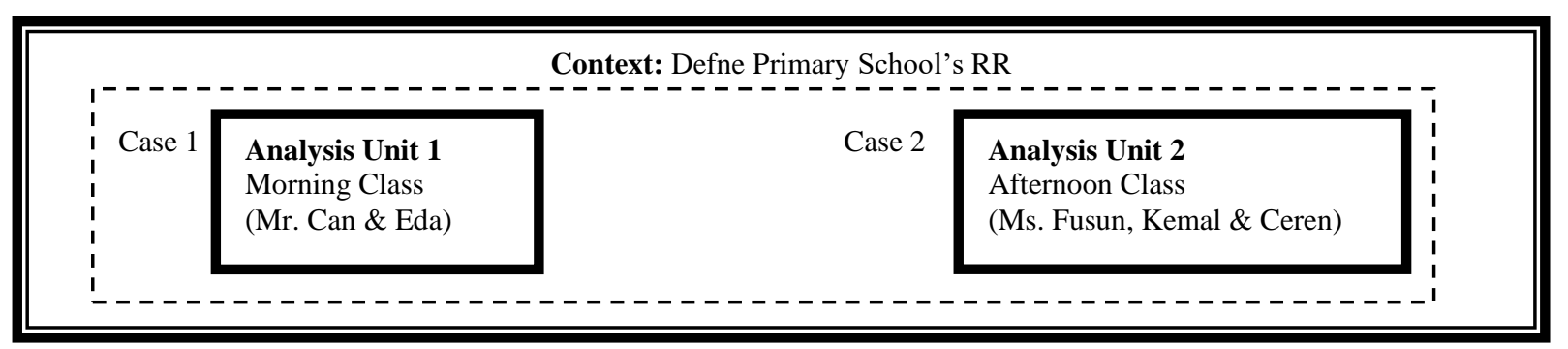

\section{Study Group}

The participants were determined by the criterion sampling method. They were included in the study under two groups. The inclusion criteria were in the following: (i) having at least five years of professional experience, (ii) being a volunteer (iii) currently working or having previously worked with SWSN, (iv) working at a primary school with an RR, and (v) having at least five years of experience in the teaching profession.

The first group of the study consisted of 10 school principals, 10 guidance counselors, and 10 RR teacher. Semi-structured interviews were held with these participants. The other participant group consisted of SWSNs. Necessary permissions were obtained from their families for their participation in the study. 


\section{Environment}

There were two different environments in this study. The researcher determined these environments using the criterion sampling method. The relevant criteria were that schools were located in the central districts of the province where the study was conducted, where children from low, middle and high-income levels came together, and schools where teachers who voluntarily participated in the interviews. The first environment was the RR of Defne Primary School. This RR was important as it was the focused environment where field notes were kept. The environment in the second group consisted of the RRs of 12 primary schools where control lists were used. These 12 RRs included the RR of Defne Primary School. These were the environments that served to determine the answer to the question "How is the physical environment of an RR?".

\section{Data Collection and Analysis}

The data was collected in the 2016-2017 academic year. In Defne Primary School, 28 field notes were recorded in Case 1, 24 field notes in Case 2. 27 and 23 images were recorded in both cases, respectively. The field notes were more than the images. The reason for taking these notes was to ensure that the participants primarily became used to the researcher. The interviews were conducted in one-on-one meetings after signing the participant forms and filling in personal information forms.

During the data analysis, multiple data collection, expert opinion, and participant confirmation were used for credibility. The field notes, participant perpectives, and document-based descriptive studies were used for transferability. For verification, intercoder reliability was examined. The images and field notes were randomly selected by three different experts. Following the application of the reliability formula, the value was calculated as $92 \%$. The ethical permission was received from Anadolu University (Protocol no. E.138135).

\section{Results}

\section{Findings Regarding the Physical Environment of the RR}

The three sub-themes of the physical environment were hardware, material, and physical conditions. It was seen that the RRs were insufficient in terms of these aspects. There were 39 materials in the Hardware Checklist. It was seen that 15 of these materials were not in any RR, while 24 materials were in different RRs. There were 47 materials in the Material Checklist. It was seen that 15 materials were not in any RR, while other materials were in different RRs. Besides, half of the participants in the interviews reported a lack of material, while nine stated that they did not have classrooms.

\section{RR Findings from Stakeholders}

Participants stated their positive opinions and the problems they had about inclusive practices and the RR. The satisfaction with the RRs, educational opportunities offered to SWSN, professional experiences, and contributions to collaboration were among the positive opinions regarding the RR. Mr. Nafi said, “...RR education, that is, providing this service to children in terms of equal opportunity is extremely positive...”. Ms. Füsun, however, stated that she did not feel any sense of belonging to RR which ensured equal opportunity for students with special needs, saying, “...I still don't see myself as a resource room teacher. I am doing this temporarily only to properly fulfill my task...”.

\section{Roles and Responsibilities of School Principals Regarding the RR Service}

The principals expressed their roles and responsibilities regarding the RR service in relation to the administrative processes of the RR. The principals stated that they fulfilled the responsibility of assigning RR teachers in two ways in accordance with the regulation and outside the regulation. Besides, they had responsibilities such as providing physical space and financial resources to the RR, inspection, and providing training to the teacher about RR. The RR supervision was interpreted by Mr. Suat as follows:

“...We are already following the entry and exit times of our children. We follow their development by contacting our teachers who work in the support room every two or three days, visiting the classes, and receiving information about the resource room from our guidance and psychological counseling teacher..."

\section{RR Guidance Activities}

The roles and responsibilities of the GCs were evaluated within the scope of guidance activities in the RR. GCs stated that they carried out various activities for RR such as supporting, informing, coordinating and 
evaluating, preparing and following up the RR program, identifying the students who would benefit from the RR and interviewing them.

\section{Collaboration in the RR Service}

The participants stated that they carried out in- and out of school activities for RR. They reported that they led the in-school RR programs, prepared the content of these programs, held regular meetings with the IEP unit, and prepared IEPs. Outside the school, only principals reported that they exchanged information about the RR with the guidance research center (GRC) and worked in coordination with the Provincial Directorate of National Education about the RR regulation. Ms. Deniz stated that she prepared the RR study program together with the school administration as follows:

“...For example, while Turkish lessons were being taught in his classroom, we understood that he should not have the same lesson in the RR and we tried to combine the course schedules. As I said, the principal gave tremendous support in this regard. We also provided support as the guidance service. We created a mutual schedule..."

\section{The Recommendations by Stakeholders Regarding RR.}

Stakeholders stated that for an ideal RR, there should be drama as well as visual-tactile, attentionenhancing, and game activities, in addition to different activity corners at RRs. Besides, they suggested that small group training activities should be organized in RRs and all students should benefit from them if necessary. They requested seminars and in-service training from the MoNE on this subject. They asked for RR guidance, supervision, and assignment of staff in RR, the arrangement of the physical environment, the assignment of qualified special education teachers in RR. The cooperation with parents and regular GRC visits were among the suggestions. Ms. Deniz stated that all students should receive service from RR irrespective of their diagnoses. Mr. Deniz stated that all students needed to receive service from the RR regardless of the diagnosis as follows:

“...I don't know why only inclusive students or students with reports should be included in the RR education. My mind gets caught in this. Yes, I wish some items could be added in line with the needs, or these practices could be continued for students who lack certain needs even without a report. I think sticking to a report is the most negative feature of RR education. If we aim to bring inclusive students together with regular students, we see that regular students also have some problems..."

\section{Findings on the Functioning of the RR}

Preparatory Works for Teaching. According to the findings, it was seen that SWSN had personal files, IEPs, and RR documents in both cases. For example, how IEPs were prepared in Case 1 was reflected in the video footage as follows: "Guidance Counselor speaks with Teacher Can at the door of the RR. Teacher Can says the following to the Guidance Counselor, "We started to teach the $3^{\text {rd }}$ group letters. But if you talk to Teacher Berrak, tell her to prepare a new IEP. She knows better". Guidance Counselor says, "I'll see Teacher Berrak, have a good lesson, and go out." (Footage: 19).

Teaching and Implementation Process in RR. It was seen that the teachers generally included methods and techniques related to error correction, repetition, modeling, feedback, and instruction. Both teachers had educational routines and included different educational adaptations during the instruction process. In Case 2, it was seen that Teacher Füsun frequently used instructional processes. Teacher Füsun's instructional adaptation, field note, was reflected in the video footage as follows: "... Kemal, tell me the number of a license plate" said the teacher. "40," said Kemal. "42 is Konya" said the teacher. He collected 40 to 42 on the blackboard. Ceren made the collection on the blackboard. Kemal started to eat. "Now it's not the eating class. Remove the food," said the teacher. "Okay," Kemal said. The teacher said "82". They argued what province it was, which had the license plate numbered $82 \ldots$... (Field Note: 3 ).

Behavioral Management. Field notes included teacher efforts to handle and eliminate inappropriate behaviors (IBs), maintain appropriate behaviors, and ensure active participation in the lesson. While teachers appeared to use different strategies to deal with IBs, it was understood that they often ignored such behaviors. In both cases, SWSN had problems in passing to RR and did not want to participate in the RR. In Case 1, at the beginning of the observation process, Eda did not come to the RR and the teacher went to look for Eda at the school, but Eda left the classroom immediately as soon as she came to RR. This transition problem was observed as follows: "... 9.11 "they started the game," said the teacher. She went out of the RR. 9.15 She went to take her from the classroom (sounds coming from the hallway). She said "Your teacher came too..." (Field Note: 5). 
Following the inclusion of the peer in the environment in Case 1, it was seen that the problem of transition to the specified RR was eliminated. The lecture held at the RR with the typically developing students was reflected in the video footage as follows:

\title{
Table 1
}

Case 1 An Example of Typically Developing Student Studying at RR (Footage 24)

\begin{tabular}{cccc}
\hline Line & \multicolumn{1}{c}{ Before behavior } & \multicolumn{1}{c}{ Behavior } & \multicolumn{1}{c}{ After behavior } \\
\hline & $\begin{array}{l}\text { The teacher says, "Look, illa } \\
\text { illa Atilla". Then she writes } \\
\text { on the blackboard, "Ata ot at } \\
\text { (Throw grass to the horse)", } \\
\text { "read read" he says. }\end{array}$ & $\begin{array}{l}\text { Eda says "Throw grass to the horse", } \\
\text { she comes to the blackboard rapidly } \\
\text { and starts to write. Eda both writes on } \\
\text { the blackboard and repeats it with the } \\
\text { teacher. And then she sits and starts to } \\
\text { write in her notebook. }\end{array}$ & $\begin{array}{l}\text { The teacher says "we are writing by } \\
\text { reading". After wring on Eda's } \\
\text { notebook, Tamer asks "Isn't it a } \\
\text { little bit skewed?". }\end{array}$ \\
\hline
\end{tabular}

Communication and Interaction in RR. When the teacher communication characteristics were examined in the field notes, it was seen that the teachers had characteristics such as using fluent and effective Turkish, being patient and accepting, empathizing, and being able to tolerate negative situations. These findings were reflected by the researcher as follows: “...I am examining the observations, and I see that both teachers use Turkish very effectively and fluently. Teacher Can especially works on literacy and the correct use of Turkish is important...".

\begin{abstract}
Discussion

\section{Views of Stakeholder}

RR stakeholders intensively expressed the problems they had rather than positive opinions and experiences about RR service. The lack of knowledge of all stakeholders (especially teachers assigned to the RR) about the RR is in line with the literature (Çağlar, 2016; Dalga, 2019; Filig, 2019; Kaplan, 2019; Kotil, 2019). Besides, this result suggested that all participants considered GCs competent for RR.
\end{abstract}

The participants reported that the RR service had many regulatory problems. Particularly, SPs stated that the permissions for opening a RR were delayed. The reason for this was the legislation. They also reported that they were able to provide RR services approximately two months following the academic year. Another problem was the implementation of the same IEP among SWSN in general education and the RR environment. This referred to the lack of preparing a separate IEP for RR. Previous studies related to RR services in Turkey draws attention to the IEP preparation problem in a similar manner (Akay, 2016; Semiz, 2018; Yazıcığlu 2019a; Yazıcı̆̆ğu 2019b; Yazıcı̆̆lu, 2020).

Due to the aforementioned problems, the responsibility belongs to the teacher assigned to the RR. However, the RR service is not performed by the teacher. The reason for this is that the counseling service, which is an indirect role for the teachers assigned in the RR, cannot be provided at the RRs. It was revealed in this study that these counseling roles and responsibilities were fulfilled by GCs.

Depending on the decision of the IEP unit, the Special Education Services Regulation states that the courses in RR can be held outside the weekend or school hours. In the Special Education Services Regulation (Art. 2 ), it is stated that the courses in RR can be held on weekend or outside the weekly course hours. However, this article contradicts the components of the RR service. RR service is reported to be the practice where SWSN receive a certain proportion of courses in a school (Wogamon, 2013). SWSN are not separated from the school environment with the RR service but IP is maintained. Only Poon-McBrayer (2004) states that training is provided outside the course hours and does not consider this as a practice of withdrawal. As Poon-McBrayer (2004) notes, providing training outside the course hours is not an RR service. Therefore, it is recommended to review the relevant article.

Therefore, the problem of classrooms generally awaits a solution. The principals provided different information on the roles of RR inspection. The fact that the principals mentioned the educational outputs of the RR proved that they ensured some kind of supervision. In this study, it was concluded that GCs were the stakeholders who took the most critical and important roles in RR service and even performed RR leadership (Yazıcıoğlu, 2020; Yazıcıoğlu, 2019a). It was observed that GCs led the RR service due to the lack of a clear role of stakeholders while maintaining their traditional responsibilities. GCs stated that they took a lot of responsibility, including preparing IEP for RR service, and were uncomfortable with this issue. Although it was reported in the 
literature that RR teacher and SP were key people in successful RR service delivery, in this study, it was determined that GCs were key people of the RR service.

\section{Discussion on the Functioning of RR}

Considering the RR process, the reason why the instruction for SWSN was successful was related to the experiences of the teachers. It was seen that RR teachers did not prepare IEPs within the scope of the preparatory activities carried out before the instruction in the primary school, but IEPs were provided by the classroom teachers of the students.

The teaching and implementation processes in the RR provide important information regarding the functioning of the RR. It is seen that teachers make serious efforts in the instruction in both cases. The field notes show that the instructional routines of teacher Can share similarities with the educational steps provided by GüzelÖzmen and Vayiç (2007). However, in this study, unlike the stated studies, the teacher made little progress, although he worked with different but variable letter groups. In the literature, it is reported that literacy interventions are successfully implemented in the RR (Mote, 2010; Williams, 2017). At this point, it should be emphasized that the interventions in the literature are carried out by a special education teacher.

During the observations, it was revealed that skills such as protecting oneself from strangers and not hitting friends were taught by the teacher Füsun and even empathy studies were included in the IEP. In literature, attention is drawn to the studies especially conducted with the support of technology in teaching methods using cognitive processes. Y1ldırım and Güven (2012) observed that SWSN exhibited problem-solving skills by empathizing with two different problem situations. In short, it should be noted that technology in RR can contribute to education in many ways and support individual education.

Finally, the teachers gave information about academic and non-academic skills within the scope of the educational outputs of RR. Despite the lack of teachers' knowledge of RR and special education, it was seen that progress was reported. In this study, different results were obtained from those of the previous studies. In addition to the advances in academic fields, the teachers stated that there was progress in social skills and self-care in the RR. In other studies, conducted in Turkey, it was reported that there was academic progress while there was a reduction in IBs (Aydın, 2015; Ünay, 2012; Kaplan, 2019; Sayan, 2019; Tamas, 2020; Yazıcıŏlu, 2020; Yazçayır, 2020).

The results obtained from different data collection tools used in this study reveal that the teachers assigned at the RR fulfill only their direct roles. However, GCs took the responsibility for coordination within the scope of counseling, which was their indirect role. It was seen that the RR teachers were only involved in the teaching activity in this process but did not prepare IEPs or held systematic meetings with the support team. It was seen that the teachers continued their traditional approach which was far from behavioral management in the field of special education. Despite all these negative points, the targeted improvements in SWSN were achieved albeit slowly.

Regarding implementation, qualified special education teachers can be assigned to the RR service, online training on RR service can be offered to teachers by using different portals of MNE. RR guides in international literature can be used in the education system as long as they are adapted to the conditions and culture of Turkey. For future studies, however, comparisons can be made for the efficacies of individual and small group training activities within the scope of the RR and different special education support programs such as special education class, RR service, and special education consultancy. 